\title{
Growing and Picking of Green Beans
}

\author{
Karl Kaack \\ Aarhus University, Kirstinebjergvej 10 Aarslev, Denmark
}

*Corresponding Author: Karl Kaack, Aarhus University, Kirstinebjergvej 10 Aarslev, Denmark.

\begin{abstract}
Abs tract: This research was initiated with an experiment regarding the importance of a corn shelter in order to improve the yield and quality characteristics of green beans with a minimum of mechanical damage of the bean pods. That was followed by studies in bean pod distribution in order to optimize bean pod composition towards the most delicious texture, colour, and flavour. The obtained data showed that the bean pod distribution was skew with a non-normal left part due to the continuously supply of new thin pods in the left part of the pod distribution and a normal distribution in the right part of the diauxi pod growth. The solution was to remove pods in sizes below five mm and avoiding pods with diameter above $11 \mathrm{~mm}$, because that included pods with delicious sensory quality characteristics. Evaluation of this hypothesis by growing and processing of ten cultivars showed possibilities for improvements of the sensory properties in sweetness, texture, mealiness and firmness of blanched and frozen green pods. Taking optimum degree days from 761 to 1046 resulted in improvements of the sensory properties of the pods from ten fields with areas from 2.2 to $11.3 \mathrm{ha}$. The applied statistical analyses showed very strong relationships between quality characteristics and the sum of degree days from sowing the seed to picking of the bean pods.
\end{abstract}

Keywords: Green bean, flavor, color, texture, taste, size

\section{INTRODUCTION}

The fresh, canned and frozen green bean presented in the supermarkets are the immature fruits from common bean (Phaseolus vulgaris L.) that are produced using a large number of genetically improved cultivars suited for growing in various climates with moderate wind, rain and temperature. Examples on this are prediction of diameter, weight and quality of apple fruit (Malus domestica ca Borkh. cv. Elstar) using climatic variables, their interactions [1], maturation and picking time for sweet and sour cherries [2). Further studies may include the effects of stage and maturity [3, 4], field behaviour and processing characteristics of Bus Blue Lake beans [5] and factors affecting yield, quality characteristics [6] and the influence of degree days on growth and yield and green beans for processing [7]. Besides must the importance of local climate measured in degree days for growth and quality characteristics are an important part of this study. Local climate, soil composition on the development of green bean pods $[3,4,8,9$, and 10]. A small study of the quality characteristics of green bean pods from the local super markets showed many significantly differences in the quality characteristics among cut, whole, canned and frozen bean pods packed in various quality classes. The pod length varied from one to thirty $\mathrm{cm}$, pod firmness varied from a few to more than twenty five $\mathrm{kg}$ and the contents of soluble solids varied from seven to twenty $g$ in one hundred g pods. Some of these examples on variations may be due to significantly differences in the local microclimate and soil characteristics. Several very valuable cultivars have been grown in horticultural praxis using a diversity of fertilizers and harvesting equipment. Besides may mechanical pod picking, long transport time from the fields to the factory, heavy washing, and diverse processing conditions such as intensive washing, cuttings, blanching, cooling and internal transport until mechanical packing of frozen pods as found previously. Because the bean plants and especially the young pods are very sensitive to the weather conditions such as low air and soil temperature and heavy wind include this research a field experiment with growing of corn plants as a shelter for bean plants and especially in order to study mechanical surface damages of the bean pods. Because the bean plant flowering, pod initiation and diauxic pod elongation occurs successively on each bean plant in dependence of the growing conditions varies the bean pod quality characteristics such as texture, sweetness, colour, and odour compounds as found previously for apples $[1,2$, $3,4,5,6]$. Besides these very important sensory properties depends the yield and quality characteristics of bean pods very much of the macro- and microclimate and the horticultural practices $[1,2]$. Therefore have previous research shown that it is necessary to use several more specific quality char- 
acteristics by evaluation of green bean pod suitability for processing by sorting, peeling, cutting, blanching or freezing of been pods $[6,7,8,9]$. Because the bean plants and especially the young and thin pods are very sensitive to the weather conditions such as low air and soil temperature and heavy wind include this research a field experiment with growing of corn plants as a shelter for bean plants in order to promote the study mechanical surface damages on the bean plants. The most important factor to consider regarding pod development are that bean plant germination, leaf development, flower formation, pod initiation and pod development occur successively according to flower development in dependence of the local micro climates. This dependence may necessarily result in a stepwise bean pod development causing significantly variations in bean pod quality characteristics such as texture, sweetness, colour and odour compounds as found previously [1, 2, 3, 4].

\section{Materials ANd Methods}

All field experiments carried out in this research included growing of green beans on sandy loams according to common praxis among growers of green beans for industrial processing of frozen whole or cut green bean pods. The first experiment was carried out in a large bean field by sowing four rows of corn seeds instead of four rows with 'Corene' seeds on the windy side of the bean plants. Determination of the effects of wind on bean plants included samples of beans from two times four rows $50 \mathrm{~m}$ in length separated $50 \mathrm{~m}$ from another four rows of beans with the cultivar 'Corene'. The experimental area with an even density of bean and corn plants was established 27th June and encompassed two times $50 \mathrm{~m}$ with four rows of green bean plants considered as replicates. The first harvest where were carried out about a week before the factory began harvesting and continued for approximately two week. The wind velocity were measured from bean sprouting to the last picking day using anemometers placed 3, 9, 18, 30, 45 and $60 \mathrm{~m}$ from the four rows of corn plants. After harvesting of the beans by hand were the bean stalk and snip removed by hand and the pods were blanched in $501 \mathrm{wa}-$ ter at $90^{\circ} \mathrm{C}$ for $3 \mathrm{~min}$, and cooled in cold water to $12.5^{\circ} \mathrm{C}$. Thereafter were the bean pods frozen using liquid carbon dioxide and stored in a freezer room kept at $-25^{\circ} \mathrm{C}$ until sensory and chemical or physically analysis. One hundred $\mathrm{g}$ bean pod cuttings $5 \mathrm{~cm}$ in length were macerated in $200 \mathrm{ml}$ distilled water using a high speed blender and applied for determination of the contents alcohol insoluble dry matter according to [10]. Determination of carbohydrates were initiated using $25.00 \mathrm{~g}$ efficiently macerated bean pod materials into a $100 \mathrm{ml}$ bottle followed by addition of $10 \mathrm{ml}$ lead acetate and addition of methanol to $100 \mathrm{ml}$ in order to remove the contents of organic acids. After two hours were $4 \mathrm{ml}$ extract filtered (Munktell 20H) and the major part of the liquid removed by gentle distillation. Finally were the extracts dried twice using 2-propanol that was removed by evaporation. Thereafter were the carbohydrates soluted in $2 \mathrm{ml}$ dry pyridine and stored for 20 hours at room temperature until addition of $100 \mu \mathrm{l}$ hexamethyldisilazane, $100 \mu \mathrm{l}$ chlortrimethylsilan and stored on a water bath at $70^{\circ} \mathrm{C}$ for 60 min. The carbohydrates were separated using a Hewlett Packard 5830 gas chromatograph equipped with a high pack stainless steel column, packed with OV1. Injector and detector temperature were 250 and $350{ }^{\circ} \mathrm{C}$ with column temperature $150-250{ }^{\circ} \mathrm{C}$ increasing with $0.5^{\circ} \mathrm{C} \mathrm{min}-1$ and the carrier gas was $\mathrm{N} 2,16 \mathrm{ml}$ min- 1 . The contents of odour compounds were measured using a modified method using the same gas chromatograph equipped with a stainless column $1 / 8 \times 16$ " filled with $10 \%$ Carbowax $20 \mathrm{M}$ on diatomite CT. The injection and detector temperature were $200{ }^{\circ} \mathrm{C}$, column temperature 30 $120^{\circ} \mathrm{C}$ increasing $0.5^{\circ} \mathrm{C}$ min- 1 , and carrier gas N2 $15 \mathrm{ml} \mathrm{min}-1$. Firmness of raw and processed beans were measured using a FMC tenderometer filled with $80 \mathrm{~g}$ bean pieces cut into $0.5 \mathrm{~cm}$ length. The contents of alcohol non-soluble dry matter were determined using a modified method according to [10]. Fifteen $g$ of macerated material plant materials were extracted using $150 \mathrm{ml} 80 \%$ ethanol and the filters were dried at $115^{\circ} \mathrm{C}$ in a vacuum chamber before weighing. The contents of chlorophyll were measured according to [11]. Frozen green beans were thawed in a microwave oven and presented as by a traditional dinner and the sensory evaluations were carried out by eight women and two men aged 28-36 years, trained for several years in sensory evaluation of processed green beans, peas, lettuce, spinach, maize and potatoes. The data from sensory evaluation in this research included use of points from 1 to 10 as the minimum and maximum points for each of the sensory properties. Statistical analysis was carried out using analyses of variances and linear regression [12].

\section{RES ULTS AND DISCUSSION}

From sprouting to picking of bean pods increased the bean and corn plant height from 0.5 to 40 and from 11 to $167 \mathrm{~cm}$, respectively. The bean plant height increased from $0.5 \mathrm{~cm}$ to $40.0 \mathrm{~cm}$ at $3 \mathrm{~m}$ shelter distance. After picking by hand or using a mechanical pod picker were the harvested materials 
mixed carefully before sampling and removal of stalk and snip and frozen using and sampling according to the experimental plans. Studies in the effects of wind on bean plants included samples of beans from two times four rows $50 \mathrm{~m}$ in length separated by four rows of beans. The bean plant height increased from $0.5 \mathrm{~cm}$ to $40.0 \mathrm{~cm}$ at $3 \mathrm{~m}$ shelter distance. Immediately after picking by hand or using a mechanical pod picker from the participating industrial producers were the bean pod materials from each replicate mixed carefully and samplings for a diversity of processing and analyses were prepared accordingly to the described and tested cautions. The relative wind velocity was at maximum by 30 , 45 and $60 \mathrm{~m} \mathrm{sec}-1$ and increased significantly in height from $1.00 \mathrm{sec}^{-1}$ at $3 \mathrm{~m}$ shelter distance to 1.03 , 1.77 and $2.62 \mathrm{~m} \mathrm{sec}-1$ at 30,45 and $60 \mathrm{~m}$, respectively.

Table 2 shows data from studies in the effects of four rows of maize plants as a shield against wind damage on bean plant tissues including stem, pod, surfaces and pod weight. The increases in stem yield, pot yield and bean damage with the increasing distances from the shelter resulted in significantly decreasing stem yield, pod yield and bean damage, whereas losses in pod weight decreased. The bean plant height was $0.5 \mathrm{~cm}$ by shelter at the distance $3 \mathrm{~m}$ and increased thereafter to maximum $40.0 \mathrm{a}$ and $32.3 \mathrm{~b} \mathrm{~cm}$ at shelter distance $3 \mathrm{~m}$ and $60 \mathrm{~cm}$, respectively. The effects of shelter on bean plant height occurred up to row distance $4.5 \mathrm{~m}$, while the effect of shelter on bean yield was significantly different at all shelter heights. Mechanical damage of beans was significantly highest by increasing shelter height from 0.5 to 2.5 and from 14.5 to $17.0 \mathrm{~m}$. Bean pod weight increased significantly with increasing shelter height (Table 1). From bean plant height $0.5 \mathrm{~cm}$ and corn plant height $11.4 \mathrm{~cm}$ 27th June to harvest 3rd September increased the height of bean and corn plant to 40 and 167 $\mathrm{cm}$, respectively. Table 1 also shows that the positive effects of shelter that occurred up to $4.5 \mathrm{~m}$ shelter only, whereas the yield of beans increased up to $8.5 \mathrm{~m}$ from the corn plant shelter and the reduction in bean damage continued up to $11.5 \mathrm{~m}$ from the corn plant shelter. The increasing effect on pod weight continued up to $17 \mathrm{~m}$ from the shelter. In the time from 27th June to 24th July was the wind velocity even, whereas it increased significantly from 24th July to 3rd September and from 3rd September to 9th October. Been plant height were uniform 27th September, increased to 12.0 after nine days and were almost constant in the remaining part of the experimental time. The bean plants were highest 3rd October and decreased thereafter significantly with time. The height of the maize plants increased from 11 to $167 \mathrm{~cm}$ and the pod growth lengths were associated to degree days as previously described for determination of optimum size, sweetness, colour and aroma compounds in apple [1]. The plant yield in t ha-1 increased up to $4.5 \mathrm{~m}$ from the shelter and total yield of beans increased up to shelter distance $8.5 \mathrm{~m}$, whereas bean damage increased up to $12.0 \mathrm{~m}$ from the shelter. The pod weight was significantly highest $0.5 \mathrm{~m}$ from the bean plants [13,14]. The linear growth and increases in dry matter has been confirmed previously [15]. The improvements in bean pod yield an improvements in quality characteristics may probably result in considerations regarding the possibilities for growing of green bean in areas with shelter in order to improve the yield and quality characteristics by growing and processing of green bean pods as shown previously in table 1 and 2 .

Studies of seven bean pod size distributions for each of the three cultivars 'Corene', 'BBL', 'Fortune' and 'Orbit' showed that the pod distribution were non-symmetrical throughout the whole picking time for these cultivars. At the left part of the bean pod distribution increased the number of bean pods non-normally from 1.0 to $9.5 \mathrm{~mm}$ at the maximum, and thereafter decreased the pod size according to a normal distribution down to pod size $12-13 \mathrm{~mm}$. These developments were tested by mathematical simulated sorting of 600 beans from each of the three cultivars 'Orbit', 'BBL', and 'Corene'. The left part of table 3 shows data from the first of seven test samples in size 2.0-5.9 mm and the right part include data from the first seven samples of pods in size 6-12 $\mathrm{mm}$ that include the applicable bean pods from the actual fields. And the right part of table 3 was used for simulation of the sorting of bean pods in two classes with pod diameter $<6 \mathrm{~mm}$ and $=>6-12 \mathrm{~mm}$. At the last picking of 'Orbit', 'BBL', and 'Corene' were the number of pods in these three classes 50/550, 87/513 and 10/581, respectively. In percentage were 8.3, 14.5 and 3.2 percent of the pods $<6 \mathrm{~mm}$ in diameter. And therefore was estimation of percentage distribution of pods necessary in order to obtain the most valuable beans by harvesting. The three distributions showed that pod setting by green beans occur according to a slow increasing s-function up to a maximum and then decreased the bean pods according to a different s-function. The significantly increasing $\beta 1$-values show that the distributions become more oblique by time. The relationship between AIS and total dry matter $(t)$ using data from four years were $\%$ AIS $=0.91 \mathrm{t}-2.46, \mathrm{r}=0.97$. 
The contents of moisture, chlorophyll, alcohol insoluble solids, soluble solids and total acidity are very valuable important quality characteristics because they promote growth and maturity during bean pod development, while moisture and chlorophyll decreased significantly as an opposite direction. Fibrousness, juiciness and hardness were the most important sensory variables for the overall acceptance of the cooked product. Therefore it was concluded that the distribution in size 2-12 $\mathrm{mm}$ were non-normal with two peeks at 5.25 and $9.25 \mathrm{~mm}$, respectively. The left part of table 3 includes the properties of 600 bean pods from the first to the seventh picking of beans from the cultivars 'Orbit', 'BBL' and 'Corene' in size 2-12 mm, that was non-normal distributed, whereas the right part with three distributions in size $=>6.0 \mathrm{~mm}$ were normally distributed, respectively. Information about the normal distribution of pod properties was obtained using the $\beta$-values that was calculated using the four moment's $\mu 1, \mu 2, \mu 3$ and $\mu 4$ as described in Kendall's Advanced Theory of Statistics and Distribution Theory [16]. These relationships data properties were carried out using quality characteristics: $\beta 1=\mu 12 / \mu 22 ; \beta 2=\mu 4 \mu 22 ; \gamma 1=\beta 0.5 ; \gamma 2=\beta 2$. The second experiment included determination of the pod yield and quality characteristics in three size classes of beans obtained by growing of the four cultivars 'Fortune', 'Orbit', 'Bush Blue Lake' and 'Corene'. The bean seeds were sown from 22nd May to 9th June and grown for four years with determination of pod yield in three size classes size classes $<7.5,7.5-11.0,>11 \mathrm{~mm}$. The pods were picked from 12th August to 1st September encompassing determination of pod size and firmness in three size distributions as shown below (Table 4).

The pod yield and firmness in size $<7.5 \mathrm{~mm}$ decreased significantly with picking time for the four cultivars, whereas the yield and firmness of the pods in the other size classes increased significantly with picking time for the four cultivars. The average yield of applicable bean pods in size 7.5-11.0 $\mathrm{mm}$ in the four years could be described using second order equations $\mathrm{y}=\mathrm{b} 0+\mathrm{blt}+\mathrm{bt} 2$ that by differentiation resulted in linear yields $y^{\prime}=b 1+2 b 2 t$, with significantly effects $(r>0.98)$. The average maximum yield of 'BBL', 'Corene', 'Fortune' and 'Orbit' in four years with irrigation were 9.5b, $12.2 \mathrm{~d}, 9.9 \mathrm{c}$ and $7.8 \mathrm{a}$ ton ha-1 with average degree days $1101 \mathrm{~d}, 1034 \mathrm{c}, 957 \mathrm{~b}$ and $819 \mathrm{a}$, respectively. The number of raw beans with pod size below $7.5 \mathrm{~mm}$ decreased significantly with picking time, whereas firmness increased significantly by increasing pod size [12, 15]. Sensory properties of blanched bean pods stored at $-25^{\circ} \mathrm{C}$ for four months with picking time. Size $<7.5 \mathrm{~mm}$ decreased with time for all cultivars and size 7.5-11 mm increased with time for 'Fortune' and 'Corene' and decreased with time for 'Orbit' and 'BBL'. Size $>11.0 \mathrm{~mm}$ did practically not occur for 'Fortune' and 'Corene', but increased with time for 'Orbit' and 'BBL'. Firmness of size $<7.5$ and 7.5-11.0 mm were not significantly different for any of the four cultivars. Sensory evaluation of mealiness, sweetness, toughness and preferences of blanched and frozen storage of the four green bean pods from the four cultivars 'Fortune', 'Orbit', 'Bush Blue Lake' and 'Corene' were picked five or six times and sorted in three sizes < 7.5, $7.5-11.0$ and $>11.0 \mathrm{~mm}$. Mealiness and toughness increased significantly with picking time for these four cultivars, whereas sweetness and preference decreased significantly with picking time (Table 4). The contents of dry matter in the four cultivars increased significantly with degree days as found previously $[13,16]$. The maximum yield of bean pods with diameter 7.5 $11.0 \mathrm{~mm}$ by growing of 'BBL' in four experimental years had maximum 9.5, 10.0, 12.0 and 11.5 days after the first day of picking. After this stage, changed pod composition rapidly with increasing dry matter content as found previously [15, 17, 18]. Mealiness increased with picking time except for 'BBL', toughness, increased whereas preference decreased with picking time, whereas sweetness and preference decreased with picking time for the four cultivars, whereas toughness increased significantly with picking time (Table 5). Therefore it seems naturally that the preference points y is determined by the sum of the product of pi and the firmness fi of the bean pods. The preference values $y$ that depends on size percentage distribution pi and firmness fi may therefore be described using a simple equation as $\mathrm{y}=\mathrm{k}(\Sigma$ pifi $) \mathrm{m}$. The number of degree days for each cultivar was calculated for four years using basis temperatures from 0 to $12^{\circ} \mathrm{C}$ by $100 \%$ relative yield of bean pods. The standard deviation (s) calculated from these data were $\mathrm{s}=\mathrm{b} 0+\mathrm{b} 1 \mathrm{x}+\mathrm{b} 2 \times 2 \mathrm{r}=0.99$ and differentiation resulted in $\mathrm{y}=\mathrm{b} 1+2 \mathrm{bx}$ showed that basis temperature for the four cultivars were 3.0, 3.8, 4.4 and $5.4{ }^{\circ} \mathrm{C}$. The average degree days for 'BBL', 'Corene', 'Fortune' and 'Orbit' were 1101, 1034, 957 and 809, respectively. Weight of percentage beans with diameter below $7.5 \mathrm{~mm}$ decreased significantly with picking time for these four cultivars. Pod firmness in sizes below $7.5 \mathrm{~mm}$ decreased with time for the four cultivars and increased in diameter size of 'Fortune' and 'Corene', whereas firmness of green beans from 'Orbit' and 'Corene' decreased with picking time. Bean in size $>11 \mathrm{~mm}$ did not occur in beans from 'Fortune' and 'Corene', while this size of 'Orbit' and 'BBL' increased with time. Meali- 
ness and toughness increased significantly with picking time, whereas sweetness and preference decreased. Bean pods in size 7.5-11.0 mm increased linearly with picking time for 'Fortune' and 'Corene', whereas weight percentage pod size decreased significantly in size $7.5-11.0 \mathrm{~mm}$ with picking time for 'Orbit' and 'Bush Blue Lake' (Table 6). The bean pod size in this research included beans with diameter < 7.5, 7.5-11.0 and > 11.0. Pod firmness in sizes below 7.5 mm decreased with time of in the four cultivars. Size 7.5-11 mm increased in diameter size of 'Fortune' and 'Corene', whereas beans from 'Orbit' and 'Corene' decreased with picking time. Bean in size $>11 \mathrm{~mm}$ did not occur in beans from 'Fortune' and 'Corene', while these sizes of 'Orbit' and 'BBL' increased with time in these two cultivars. Mealiness and toughness increased significantly with picking time, whereas sweetness and preference decreases with picking time $[12,15]$. The bean pod size in this research included beans with diameter $<7.5,7.5-11.0$ and $>11.0$. This research encompassed picking of 600 pods seven times through the maturation period for the three cultivars 'Orbit', 'BBL' and 'Corene' showed that the pod diameter varied from 2 to $13 \mathrm{~mm}$ that were distributed according to normal functions. Pod firmness in sizes below $7.5 \mathrm{~mm}$ decreased with time for the four cultivars. Size 7.5-11.0 $\mathrm{mm}$ increased in diameter size of 'Fortune' and 'Corene', whereas beans from 'Orbit' and 'Corene' decreased with picking time. Bean in size $>11 \mathrm{~mm}$ did not occur in beans from 'Fortune' and 'Corene', while this size of 'Orbit' and 'BBL' increased with time in these two cultivars. The relationships between the basic sensory properties of green beans were confirmed using sensory analysis showing that there was a significantly dependence between odour and preference and that preference were negatively associated with mealiness and toughness while sweetness and odour contributed significantly to such preference (Table 7). Fibrousness, juiciness and hardness belongs also to the most important sensory variables for the overall acceptance of the picked raw bean materials obtained by carefull analyses of the qualities of samples carried out in order to reduce the mechanical damages during picking and be a were of proper care by picking and processing in order to a avoid hard treatments of the tin bean pods $[18,19]$. The changes in sensory properties during the picking period could be described using the linear relationships between the sensory properties $(\mathrm{y})$ and the four sensory characteristics including mealiness, toughness, sweetness, preferences and pod diameter (Table 7). Toughness increased in 'Orbit', was non-significantly different for 'BBL' and decreased significantly with diameter size. The diameter showed linear relationships between the sensory properties in days after first picking and pod diameter in $\mathrm{mm}$ as found previously $[15,17]$. Mealiness of 'Orbit', 'BBL' and 'Corene' increased significantly, whereas preference decreased significantly in pod size with picking time. 'Corene' decreased, was constant for 'BBL' and decreased significantly with pod size for 'Corene'. Preference decreased with increasing pod size for 'Orbit', 'BBL' and 'Corene'. Mealiness of 'Orbit', 'BBL' and 'Corene' increased significantly with increasing pod size and were almost constant with picking time. Sensory evaluation of mealiness showed that the sensory properties depended significantly on the levels of mealiness between cultivars with the highest rate and level in 'BBL'. The levels of toughness were lowest in 'Orbit', highest in 'Corene' and low rates of changes occurred during pod maturation (Table 8). Toughness of 'Orbit' increased significantly with increasing pod size, was constant for BBL and decreased with picking time for 'Corene'. Sweetness and preference decreased with pod size in the three cultivars and were almost constant with picking time. When the bean pod size increases then the yield of bean pods increases significantly. Data from The preferences were lowest in 'BBL' and decreased significantly during pod maturation. The relationship between preference and the three sensory properties was estimated using multiple regression analysis with negative effects of mealiness and toughness's, whereas the sweetness increased significantly as described above: $\ln$ preference $=6.03-0.50$ mealiness +0.33 sweetness -0.28 toughness. $r=0.94$. The conclusion on this equation is that mealiness decreased, sweetness increased and toughness increased during the period of early growth and especially during the pod development and maturation with focusing on growing of green beans with reduced stringiness, low contents of fibre and a diversity of other compounds that contributes to non-soluble solids and toughness of the beans. The preference was lowest in 'BBL' and decreased significantly during pod maturation. Sweetness decreased significantly towards the picking points and the relationship between preference and the three other sensory properties were estimated using multiple regression analysis with negative effects of mealiness and toughness, whereas sweetness increased significantly. Preference $\mathrm{y}=6.03-0.50$ mealiness + 0.33sweetness- 0.22toughness. $r=0.94$. The levels of toughness were lowest in 'Orbit', highest in 'Corene' and low rates of changes occurred during maturation (Table 8). An experiment with growing of the four bean cultivars 'Fortune', 'Orbit', 'Bush Blue Lake' and 'Corene' included sampling of bean pods in three size classes $<7.5,7.5-11.0$ and $>11 \mathrm{~mm}$. The beans were blanched and stored at - 
$25^{\circ}$ until preparation by cooking and evaluation of toughness, sweetness and preference (Table 9) by the members of the sensory panel (Table 9 ). The preference values pi found by sensory analysis were combined using $\mathrm{y}=\mathrm{k}$ ( $\Sigma$ pifi) $\mathrm{m}$ for each bean pod size encompassing the sum of sensory properties firmness, toughness, sweetness and preference. Using the products sums of number of bean pods and the measured bean pod diameter resulted in more quality characteristics. Data from sensory Table 9 shows bean pod size distribution, average preference points for the three cultivars, product sums and the three equations that confirm the strong relationship for the three cultivars. Table 10 shows data from eight $\mathrm{n}$ fields with growing of green bean pods in five bean pod sizes. The yield of beans varied from 2.8 to 4.4 ton ha- 1 and the contents of dry matter, alcohol insoluble compounds and chlorophyll varied significantly and linearly between total yield, AIS, chlorophyll, and degree days (Table 8-14). The analyses obtained by gas chromatography showed presence of 1-octen-3-ol and cis-hexanol that contribute significantly to the odour of green bean pod as described by the sensory panel. Table 11 shows the relationships between cultivar, sowing and picking time, degree days and the changes in degree days for the eight fields with growing of five cultivars [15]. Besides shows table 11 shows the relationships between yields, dry matter, alcohol insoluble compounds and chlorophyll in green bean pods from two, alcohol insoluble compounds increases with picking time, whereas the contents of chlorophyll decreases with picking time as found previously [15]. The very high correlation coefficients show important possibilities using the predictions for determination Fibrousness, juiciness and hardness belongs also to the most important sensory variables for the overall acceptance of the picked raw bean materials obtained by carefully analyses of the qualities of samples carried out in order to reduce the mechanical damages during picking and be a were of proper care by picking and processing in order to avoid hard treatments of the tin bean pods [18] the quality of canned snap beans. [19]. The industrial harvesting of the bean pods are carried out by ripping of the leaves and pods from the plants when they are mature where the pods occur in several seizes from quite small with diameter below $7 \mathrm{~mm}$ to pods with a diameter $15 \mathrm{~mm}$. Even a minimum mechanical treatment of the bean pod surface causes release of enzymes that cause release of organic compounds from linoleic and linolenic acids that occurs in the leaf surfaces and release very non-attractive odour making organic compounds enzymatically (Table 10). Pod diameter decreases with time in the first three columns and increases with time in the last three columns. That may be characterized as a turning point in pod development because the bean pods size increase in length in the left part of the table and increases in diameter in the right part (Table 13). Degree days increased linearly from 80 to 144 degree days depending on cultivar, sowing time and degree days with maximum 80, 81, 95, 115, 127, 132, 142 and 144 degree days and that contributes to data presented previously [1] (Kaack 1979). Pod diameter and w/w\% pods from 'BBL' and 'Orbit' varied significantly in firmness and $\mathrm{w} / \mathrm{w} \%$ versus time and pod diameter, respectively (Table 14). Firmness of BBL varied from $181 \mathrm{~kg}$ to $199 \mathrm{~kg}$ whereas firmness of 'Orbit' changes from 180 to $225 \mathrm{~kg}$. Pod weights were at maximum diameter, except for the cultivar 'Orbit' with equal pod weight at four pod sizes. Fructose was at maximum for pod size 9-11 mm except for 'Orbit' with equal level of fructose at all pod sizes (Table 14). These data corresponds with previous research in growing of green beans with determination of green been contents of carbohydrates $[12,18.17,20]$. And the sugars in snap bean are very important as described above because the sugars contribute significantly to the flavour of green beans and the chlorophyll are important for the green colour [17, 18]. Sugars promote flavour and acceptance of vegetables, but they also alter the perception of flavours associated with organic acids [22]. The pattern in the data from measurement of pod weight, contents of sugars and inositol were in accordance with the results described previously [23]. Experiments with blanching of beans in one and two steps have shown that inactivation of peroxidase requires more heating than inactivation of the enzymes that may give rice to off flavour from aldehydes that are degraded during blanching of green beans. During pre-blanching at $65-75^{\circ} \mathrm{C}$ and final blanching to chlorophyll degradation may the colour change according to the color values ($\mathrm{a} / \mathrm{b}$ ) that increases with time which means that the colour of the beans changes from green to yellow green [1]. Bean pod size, length, and bean pod weight varies between cultivars (Table 15). Sweetness, sourness, firmness and odour compounds are very important contributors to taste and firmness and they contribute to human health and life time [24, 25, 26, and 27]. In vegetables, are sourness, associated with organic acids, bitterness is often connected with bitterness, saltiness is attributable to sodium or potassium and sweetness is the result from occurrence with organic acid and sweetness are due to carbohydrates including glucose, fructose and sucrose (Golaszewski, 2003). The contents of moisture, chlorophyll, alcohol insoluble solids, soluble solids and total acidity are very important quality characteristics because they promote growth and maturity of green bean increased significant- 
ly during bean pod development, while moisture and chlorophyll decreased significantly as an opposite direction. Fibrousness, juiciness and hardness were the most important sensory variables for the overall acceptance of the cooked product [26].

Alcohol insoluble solids, soluble solids, and total acidity increased significantly during development, while moisture and chlorophyll showed an opposite trend. Fibrousness, juiciness and hardness were the most important sensory variables for the overall acceptance of the cooked product [20]. Fibrousness, juiciness, firmness are included in the hardness are very important sensory variables for the overall acceptance of the prepared cooked product. Alcohol insoluble solids, soluble solids, and total acidity increased significantly during development, while moisture and chlorophyll showed an opposite trend (Table 17). Fibrousness, juiciness and hardness belongs also to the most important sensory variables for the overall acceptance of the picked raw bean materials are obtained by careful analyses of the qualities of samples carried out in order to reduce the mechanical damages during picking and be aware of proper care by picking and processing in order to avoid hard treatments of the tin bean pods [18]. If the reproductive period of bean coincides with high summer temperatures then due to abscission of buds and flowers there is a significant decrease of productivity. In late sowing, growth, yield and yield components decrease because of a short vegetation period. Delayed planting decreased the number of days as well as the thermal time from emergence to harvest. The analysis of the effects of developmental stage on bean quality variables showed that stronger relationships could be obtained if thermal time was evaluated from the beginning of the flowering period and not from sowing and that thermal time had to account for a high temperature reduction of thermal time accumulation. The yield and timing of development can be estimated from the harvests of bean varieties. Using the information, the approximate maturity date of the crop can be predicted by using the average number of degree days in the particular month for particular location. The developmental stages of processing beans can be predicted with thermal time accumulation [14]. Experiments with one and two step blanching of green beans have been carried out and that included of peroxidase that require more than inactivation of the enzymes that give rise to off flavour from aldehydes because that results in inactivation of the enzymes that give rise to losses in flavour [1]. Pre-blanching at $65-75^{\circ} \mathrm{C}$ and final blanching resulted in degradation of chlorophyll to pheophytin and that causes changes of the surface colour expressed as - $\mathrm{a} / \mathrm{b}$ increases with time. And that means that the colour of the beans changes from green to yellow. Preblanching of green beans at $65-75^{\circ} \mathrm{C}$ increases the firmness of the beans linearly with time [1]. The firmness of beans, decreased during blanching according to a first order reaction with $40 \mathrm{kcal}$ and 7 mole activation energy. Preblanching at $65-75^{\circ} \mathrm{C}$ increased the firmness of the beans linearly with treatment time. This increase in firmness was stable after final blanching at $75^{\circ} \mathrm{C}$ and even after final blanching at $95{ }^{\circ} \mathrm{C}$ of frozen beans. Respiration rates were higher in beans that were held under high temperatures and a fast flow rate. Sensory ratings for color and general appearance were higher on beans stored under a slow flow rate. [18]. Beans stored under a fast flow rate were higher in \% seed, fiber, hemicellulose and cellulose. Browning was more severe in beans stored at a fast flow rate. As storage times and temperatures were increased, beans decreased in greenness ('a') and sensory scores. Shear press values, \% seed, fibre, total sugar and cellulose increased in the canned beans as storage times and temperatures were increased. The beans that were blanched in rotary steam were lighter in colour and less firm than those blanched in water. Respiration rates were higher in beans that were held under high temperatures and a fast flow rate. Sensory ratings for colour and general appearance were higher on beans stored under a slow flow rate. Beans stored under a fast flow rate were higher in \% seed, fibre, hemicellulose and cellulose. Browning was more severe in beans stored at a fast flow rate. As storage times and temperatures were increased, beans decreased in greenness ('-a') and sensory scores. Shear press values, \% seed, fibre, total sugar and cellulose increased in the canned beans as storage times and temperatures were increased. The beans that were blanched in rotary steam were lighter in colour and less firm than those blanched in water.

Table1. Effects of Shelter Distance, Relative Wind Velocities ( $\mathrm{m} \mathrm{Sec}^{-1}$ ) Bean Plant and Maize Plant Heights.

\begin{tabular}{|l|l|l|l|l|l|l|}
\hline & \multicolumn{7}{|c|}{ Shelter distance, $\mathbf{~ m}$} \\
\hline \multicolumn{1}{|c|}{ Time } & 3 & 9 & 18 & 30 & 45 & 60 \\
\hline & \multicolumn{7}{|c|}{ Relative wind velocities m sec $\mathbf{- 1}^{-1}$} \\
\hline 27 Jun & $1.0 \mathrm{ap}$ & $0.95 \mathrm{cr}$ & $1.03 \mathrm{cp}$ & $1.03 \mathrm{cp}$ & $1.02 \mathrm{cp}$ & $1.02 \mathrm{cp}$ \\
\hline 24 Jun & $1.0 \mathrm{au}$ & $1.20 \mathrm{bt}$ & $1.71 \mathrm{br}$ & $17.6 \mathrm{bq}$ & $1.63 \mathrm{bs}$ & $1.77 \mathrm{bp}$ \\
\hline 4 Sep & $1.0 \mathrm{au}$ & $1.40 \mathrm{at}$ & $2.25 \mathrm{as}$ & $2.32 \mathrm{ar}$ & $2.76 \mathrm{ap}$ & $2.62 \mathrm{aq}$ \\
\hline & \multicolumn{7}{|c|}{ Bean plant size, cm } \\
\hline
\end{tabular}




\begin{tabular}{|l|l|l|l|l|l|l|}
\hline 27 Jun & $0.5 \mathrm{cp}$ & $0.5 \mathrm{bp}$ & $0.5 \mathrm{cp}$ & $0.5 \mathrm{cp}$ & $0.5 \mathrm{cp}$ & $0.5 \mathrm{cp}$ \\
\hline 24 Sep & $10.3 \mathrm{bq}$ & $12.0 \mathrm{ap}$ & $10.8 \mathrm{br}$ & $11.3 \mathrm{bq}$ & $10.0 \mathrm{brw}$ & $11.8 \mathrm{bq}$ \\
\hline $3^{\text {rd }}$ Sep & $40.0 \mathrm{ap}$ & $36.0 \mathrm{aq}$ & $30.8 \mathrm{ar}$ & $32.0 \mathrm{ar}$ & $28.8 \mathrm{as}$ & $32.3 \mathrm{ar}$ \\
\hline
\end{tabular}

Table2. Stem Yield, Pod Yield and Bean Damage on Bean Plants by Shelter + and - without Shelter.

\begin{tabular}{|c|c|c|c|c|c|c|c|c|c|c|c|c|}
\hline Distance & \multicolumn{3}{|c|}{ Stem yield, t ha ${ }^{-1}$} & \multicolumn{3}{|c|}{ Pod yield, tha-1 } & \multicolumn{3}{|c|}{ Bean damage $\%$} & \multicolumn{3}{|c|}{ Pod weight, g } \\
\hline $\mathbf{m}$ & + & - & t ha $^{-1}$ & + & - & t ha' ${ }^{-1}$ & + & - & loss & + & - & $\operatorname{los} S$ \\
\hline 0.5 & $19.8 \mathrm{fp}$ & $15.2 \mathrm{fq}$ & $9.6 \mathrm{cr}$ & 7.0dp & $4.2 \mathrm{qv}$ & 2.8 & $38.4 \mathrm{eq}$ & $59.2 \mathrm{cp}$ & $-20.8 \mathrm{~h}$ & 3.9ap & $2.9 \mathrm{cp}$ & $1.0 \mathrm{a}$ \\
\hline 2.5 & $26.6 \mathrm{cp}$ & $18.2 \mathrm{eq}$ & 8.4ar & $8.8 \mathrm{bp}$ & $5.2 \mathrm{fu}$ & 3.6 & $49.4 d q$ & $61.9 \mathrm{cp}$ & $-12.5 \mathrm{~g}$ & 3.9ap & $2.9 \mathrm{cq}$ & $1.0 \mathrm{a}$ \\
\hline 4.5 & 29.9ap & $24.4 \mathrm{dq}$ & $5.0 \mathrm{br}$ & $8.9 \mathrm{bp}$ & $6.0 \mathrm{et}$ & 3.9 & $55.2 \mathrm{cp}$ & 53.1dp & $2.1 \mathrm{~d}$ & $3.6 \mathrm{bp}$ & $2.7 \mathrm{dq}$ & $0.9 \mathrm{a}$ \\
\hline 6.5 & $24.4 \mathrm{dp}$ & $25.2 \mathrm{cp}$ & $-0.8 \mathrm{~d}$ & $7.9 \mathrm{cp}$ & $6.9 \mathrm{cr}$ & 1.0 & $66.4 \mathrm{bp}$ & $60.3 \mathrm{cq}$ & $6.1 \mathrm{a}$ & $3.4 \mathrm{bp}$ & $2.9 \mathrm{cq}$ & $0.5 \mathrm{~b}$ \\
\hline 8.5 & $28.6 \mathrm{bq}$ & $29.1 \mathrm{bp}$ & $-0.5 \mathrm{dr}$ & 9.6ap & 9.4ap & 0.2 & $63.7 \mathrm{bp}$ & $57.7 \mathrm{dq}$ & $5.4 \mathrm{~b}$ & $3.6 \mathrm{bp}$ & 3.5ap & $0.1 \mathrm{c}$ \\
\hline 11.5 & $27.8 \mathrm{bp}$ & $32.2 \mathrm{ap}$ & $-4.4 \mathrm{er}$ & $9.2 \mathrm{dp}$ & $8.7 \mathrm{bq}$ & -0.5 & 67.8ap & $63.8 \mathrm{bq}$ & $4.0 \mathrm{c}$ & $3.2 \mathrm{cp}$ & $3.1 \mathrm{bp}$ & $0.1 \mathrm{c}$ \\
\hline 14.5 & $21.6 \mathrm{eq}$ & $22.9 \mathrm{dp}$ & $-1.3 \mathrm{fr}$ & $8.7 \mathrm{cp}$ & $6.5 \mathrm{ds}$ & $0.1 \mathrm{f}$ & $65.7 \mathrm{aq}$ & 72.0ap & $6.3 \mathrm{e}$ & $3.3 \mathrm{cp}$ & $3.0 \mathrm{cq}$ & $0.3 b$ \\
\hline
\end{tabular}

Table3. Size Distribution of 'Orbit', 'BBL' and 'Corene'. Pod Distribution, $m m, \beta 1=0, \beta 2=3$ and $\gamma 2<0$.

\begin{tabular}{|c|c|c|c|c|c|c|c|c|c|c|c|}
\hline \multicolumn{3}{|c|}{ Cultivar } & \multicolumn{3}{|c|}{ Bean } & \multicolumn{3}{|c|}{ All pods $2-12 \mathrm{~mm}$} & \multicolumn{3}{|c|}{ All pods, 6 - $12 \mathrm{~mm}$} \\
\hline 9. Aug & No & $\bar{\beta}$ & $\gamma 1$ & $\overline{\beta 2}$, & $\gamma 2$ & $\overline{\beta 1}$ & $\gamma 1$ & $\boldsymbol{\beta 2}$ & $\gamma 2$ & $<6$ & $=>6$ \\
\hline Orbit & 600 & $0.8 \mathrm{f}$ & $0.9 \mathrm{~d}$ & $2.6 \mathrm{~h}$ & $-0.4 f$ & 0 & 0 & 1.7 & $-1.25 \mathrm{e}$ & $211 b$ & $389 f$ \\
\hline 116 & "“ & $0.9 f$ & $1.0 \mathrm{~d}$ & $2.3 \mathrm{~h}$ & $-0.7 \mathrm{~g}$ & 0 & $0.1 \mathrm{e}$ & 1.7 & $-1.34 d$ & $281 \mathrm{a}$ & $319 \mathrm{~g}$ \\
\hline $13 "$ & "“ & $3.8 \mathrm{e}$ & $2.0 \mathrm{c}$ & $5.1 \mathrm{e}$ & $2.1 \mathrm{e}$ & $0.4 \mathrm{c}$ & $0.7 \mathrm{c}$ & 2.4 & $-0.6 c$ & $163 c$ & $437 \mathrm{e}$ \\
\hline $16 "$ & “" & $6.6 b$ & $2.6 b$ & $7.3 \mathrm{~d}$ & $4.3 d$ & $0.1 \mathrm{~d}$ & $0.3 \mathrm{~d}$ & 2.2 & $-0.8 b$ & 121d & $479 d$ \\
\hline $18 "$ & “" & $5.4 \mathrm{c}$ & $2.3 b$ & 5.6ef & $2.6 \mathrm{c}$ & $1.4 \mathrm{~b}$ & $1.2 \mathrm{~b}$ & 3.8 & $0.8 b$ & $89 \mathrm{e}$ & $511 \mathrm{c}$ \\
\hline $20 "$ & "“ & $7.0 \mathrm{a}$ & 2.7 & $6.9 \mathrm{e}$ & $3.9 \mathrm{~b}$ & $1.4 \mathrm{~b}$ & $1.2 \mathrm{~b}$ & 4.1 & $1.1 \mathrm{a}$ & $71 \mathrm{f}$ & $529 \mathrm{~b}$ \\
\hline $23 "$ & "“ & $4.4 d$ & $3.8 \mathrm{a}$ & $11.6 \mathrm{~b}$ & $8.6 a$ & $3.5 \mathrm{a}$ & $1.9 \mathrm{a}$ & 4.5 & $1.3 \mathrm{a}$ & $50 \mathrm{~g}$ & $550 \mathrm{a}$ \\
\hline BBL “ & " & $0.4 d$ & $0.7 \mathrm{~b}$ & $2.4 \mathrm{~h}$ & $-0.6 c$ & 0.8 & $0.9 \mathrm{~b}$ & $1.4 \mathrm{e}$ & $-1.6 c$ & $433 a$ & $167 f$ \\
\hline 20 " & "“ & $0.3 d$ & $0.6 b$ & $1.7 \mathrm{i}$ & $-1.3 e$ & $0.7 \mathrm{c}$ & $0.8 \mathrm{~b}$ & $2.8 \mathrm{~b}$ & $-0.2 \mathrm{a}$ & $255 b$ & $345 \mathrm{e}$ \\
\hline 23 " & “6 & $0.2 \mathrm{~d}$ & $0.5 b$ & $2.1 \mathrm{~h}$ & $-0.9 c$ & $0.0 \mathrm{c}$ & $0.2 \mathrm{c}$ & $1.8 \mathrm{~d}$ & $-1.2 b$ & $191 c$ & $409 d$ \\
\hline 25 " & "“ & $0.2 \mathrm{~d}$ & $0.5 b$ & $0.6 \mathrm{j}$ & $-2.4 \mathrm{e}$ & $0.0 \mathrm{c}$ & $0.2 \mathrm{c}$ & $1.8 \mathrm{~d}$ & $-1.2 b$ & $158 d$ & $442 c$ \\
\hline $27 \quad$ " & “6 & $0.6 c$ & $0.8 \mathrm{~b}$ & $2.1 \mathrm{~h}$ & $-0.9 \mathrm{~d}$ & $0.2 \mathrm{c}$ & $0.5 c$ & $2.0 \mathrm{c}$ & $-1.0 b$ & $122 \mathrm{e}$ & $478 \mathrm{~b}$ \\
\hline $30 " 6$ & " & $2.4 a$ & $1.5 \mathrm{a}$ & $3.2 \mathrm{~g}$ & $2.0 \mathrm{a}$ & $2.1 \mathrm{a}$ & $1.5 \mathrm{a}$ & $3.9 \mathrm{a}$ & 0.9 & $87 f$ & $513 a$ \\
\hline 1 Sep & “" & $1.7 \mathrm{~b}$ & $1.3 \mathrm{a}$ & $3.3 \mathrm{~g}$ & $0.3 b$ & 0.2 & $0.5 \mathrm{e}$ & 2.2 & -0.8 & $87 f$ & $513 a$ \\
\hline Corene & “" & $1.2 \mathrm{~d}$ & $1.1 \mathrm{e}$ & $2.6 \mathrm{~h}$ & $-0.4 b$ & $2.2 b$ & $1.5 \mathrm{c}$ & $2.8 \mathrm{a}$ & -0.2 & 264 & $336 f$ \\
\hline $23 \mathrm{Aug}$ & “" & $0.5 \mathrm{c}$ & $0.7 \mathrm{f}$ & $1.3 \mathrm{i}$ & $-1.7 \mathrm{e}$ & $0.3 \mathrm{~d}$ & $0.5 \mathrm{e}$ & $1.1 \mathrm{~d}$ & $-1.9 \mathrm{~d}$ & $360 \mathrm{a}$ & $360 \mathrm{e}$ \\
\hline $27 \quad$ " & “" & $3.1 \mathrm{a}$ & $1.7 d$ & $3.6 \mathrm{~g}$ & $0.6 \mathrm{~d}$ & $0.4 \mathrm{~d}$ & $0.6 \mathrm{~d}$ & $1.7 \mathrm{c}$ & $-1.3 c$ & $125 b$ & $475 d$ \\
\hline 30 " & “" & $2.3 b$ & $1.5 \mathrm{~d}$ & $2.7 \mathrm{~h}$ & $-0.3 \mathrm{f}$ & $1.9 \mathrm{c}$ & $1.4 \mathrm{c}$ & $2.5 b$ & $-0.5 b$ & $107 \mathrm{c}$ & $479 d$ \\
\hline 1 Sep & "“ & $4.9 \mathrm{a}$ & $2.2 \mathrm{c}$ & $4.7 \mathrm{f}$ & $1.7 \mathrm{c}$ & $1.7 \mathrm{c}$ & $1.3 \mathrm{c}$ & $2.4 \mathrm{~b}$ & $-0.6 b$ & $107 \mathrm{c}$ & $493 c$ \\
\hline 36 & " & $13.3 \mathrm{a}$ & $3.7 b$ & $9.9 \mathrm{c}$ & $6.9 \mathrm{~b}$ & $2.1 \mathrm{~b}$ & $1.5 b$ & $2.5 b$ & $-0.4 b$ & 51d & $549 \mathrm{~b}$ \\
\hline 6 “ & “" & $48.8 \mathrm{a}$ & $7.0 \mathrm{a}$ & $30.2 \mathrm{a}$ & $27.2 \mathrm{~s}$ & $6.8 \mathrm{a}$ & $2.1 \mathrm{a}$ & $2.5 \mathrm{a}$ & $4.5 \mathrm{a}$ & $19 \mathrm{e}$ & 581a \\
\hline
\end{tabular}

Table4. Pod Diameter and Firmness of Raw Beans from Four Bean Cultivars in Three Sizes. 'Fortune', 'Orbit', 'BBL' And 'Corene' were Picked Five and Six Times from 12th to 31 st August.

\begin{tabular}{|c|c|c|c|c|c|c|c|c|c|c|c|c|}
\hline & \multicolumn{3}{|c|}{ Size, $\mathbf{m m}$} & \multicolumn{3}{|c|}{ Firmness, kg } & \multicolumn{3}{|c|}{ Size, $\mathbf{m m}$} & \multicolumn{3}{|c|}{ Firmness, kg } \\
\hline Days & $<7.5$ & $7.5-11.0$ & $>11.0$ & $<7.5$ & $7.5-11$ & $>11.0$ & $<7.5$ & $7.5-11.0$ & $>11$ & $<7.5$ & $7.5-11.0$ & $>11$ \\
\hline & \multicolumn{6}{|c|}{ Fortune } & \multicolumn{6}{|c|}{ BBL } \\
\hline 1 & $23 a q$ & $77 \mathrm{dp}$ & - & $197 \mathrm{aq}$ & $223 b p p$ & - & $26 \mathrm{aq}$ & $74 c$ & - & $177 \mathrm{dp}$ & $158 \mathrm{~d}$ & $\dot{-}$ \\
\hline 3 & $11 \mathrm{bq}$ & $89 \mathrm{cp}$ & - & $158 \mathrm{dq}$ & 203 ep & - & $12 \mathrm{aq}$ & 88ap & - & 185ap & $165 c$ & - \\
\hline 6 & $9 \mathrm{cq}$ & $90 \mathrm{bp}$ & $1 \mathrm{a}$ & $173 \mathrm{cq}$ & $209 \mathrm{dp}$ & - & $8 \mathrm{cq}$ & $80 b p$ & $12 \mathrm{dr}$ & 187ap & $166 c$ & $154 \mathrm{c}$ \\
\hline 9 & $7 \mathrm{cq}$ & $91 \mathrm{bp}$ & $2 \mathrm{a}$ & $188 \mathrm{bq}$ & $220 \mathrm{cp}$ & - & $6 \mathrm{dq}$ & $64 \mathrm{ep}$ & $30 \mathrm{cr}$ & $183 b p$ & $166 c$ & $154 \mathrm{c}$ \\
\hline 13 & $6 \mathrm{cq}$ & 93ap & $1 \mathrm{a}$ & $198 \mathrm{aq}$ & 231ap & - & $4 \mathrm{eq}$ & $54 \mathrm{fp}$ & $42 \mathrm{br}$ & $181 \mathrm{cp}$ & $176 b$ & $163 \mathrm{~b}$ \\
\hline \multirow[t]{2}{*}{16} & & & & & & & $1 \mathrm{fq}$ & $49 \mathrm{gp}$ & $50 \mathrm{ar}$ & $181 \mathrm{cp}$ & $198 \mathrm{a}$ & $188 \mathrm{a}$ \\
\hline & \multicolumn{6}{|c|}{ Orbit } & \multicolumn{6}{|c|}{ Corene } \\
\hline 1 & $12 \mathrm{a}$ & $86 a$ & $2 \mathrm{c}$ & $166 \mathrm{a}$ & $181 \mathrm{~b}$ & - & $21 \mathrm{a}$ & $79 \mathrm{c}$ & 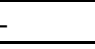 & $180 \mathrm{dq}$ & 196dp & - \\
\hline 3 & $6 \mathrm{~b}$ & $87 \mathrm{a}$ & $7 \mathrm{~b}$ & $158 b$ & $171 \mathrm{e}$ & $182 \mathrm{c}$ & $16 \mathrm{~b}$ & $79 \mathrm{c}$ & - & $174 \mathrm{eq}$ & $201 \mathrm{cp}$ & - \\
\hline 6 & $6 \mathrm{~b}$ & $66 \mathrm{~d}$ & $28 \mathrm{a}$ & $167 \mathrm{a}$ & $174 d$ & $186 b$ & $14 \mathrm{c}$ & $86 b$ & - & $186 \mathrm{cq}$ & $195 \mathrm{dp}$ & - \\
\hline 9 & $8 \mathrm{c}$ & $43 c$ & $49 a$ & $161 \mathrm{a}$ & $177 \mathrm{c}$ & $196 \mathrm{a}$ & $7 d$ & $93 a$ & - & $192 \mathrm{bq}$ & $201 b p$ & - \\
\hline 13 & $4 d$ & $46 a$ & $50 \mathrm{a}$ & $168 \mathrm{a}$ & $197 \mathrm{a}$ & - & $6 \mathrm{~d}$ & $94 a$ & 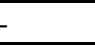 & $195 \mathrm{aq}$ & 206ap & \\
\hline
\end{tabular}

Table5. Mealiness, Sweetness, Toughness and Preference of Green Bean Pods from Four Cultivars.

\begin{tabular}{|c|c|c|c|c|c|c|c|c|c|c|c|c|}
\hline Cultivar & \multicolumn{5}{|c|}{ Mealisness } & \multicolumn{5}{c|}{ Sweetness } \\
\hline Fortune & $4.1 \mathrm{at}$ & $4.0 \mathrm{as}$ & $5.3 \mathrm{ar}$ & $7.6 \mathrm{aq}$ & $8.3 \mathrm{ap}$ & & $5.5 \mathrm{ap}$ & $4.9 \mathrm{bq}$ & $3.1 \mathrm{cq}$ & $2.1 \mathrm{dr}$ & $2.4 \mathrm{cs}$ & \\
\hline Orbit & $2.4 \mathrm{bt}$ & $2.5 \mathrm{cs}$ & $3.6 \mathrm{br}$ & $3.9 \mathrm{dq}$ & $5.4 \mathrm{cap}$ & & $4.8 \mathrm{cp}$ & $4.5 \mathrm{bq}$ & $4.3 \mathrm{ar}$ & $2.9 \mathrm{cs}$ & $2.3 \mathrm{ct}$ & \\
\hline
\end{tabular}




\begin{tabular}{|c|c|c|c|c|c|c|c|c|c|c|c|c|}
\hline BBL & $3.9 \mathrm{ct}$ & $3.6 \mathrm{bs}$ & $3.4 \mathrm{cr}$ & $3.8 \mathrm{dq}$ & $4.0 \mathrm{dp}$ & $5.8 \mathrm{~b}$ & $6.5 \mathrm{ap}$ & $4.6 \mathrm{cq}$ & $4.1 \mathrm{ar}$ & $5.9 \mathrm{as}$ & $5.1 \mathrm{at}$ & $4.1 \mathrm{a}$ \\
\hline Corene & $3.0 \mathrm{dt}$ & $3.5 \mathrm{bs}$ & $5.3 \mathrm{ar}$ & $6.5 \mathrm{bq}$ & $6.5 \mathrm{bp}$ & & $4.9 \mathrm{cp}$ & $4.4 \mathrm{dq}$ & $4.0 \mathrm{ar}$ & $3.5 \mathrm{bs}$ & $3.9 \mathrm{bt}$ & \\
\hline \multicolumn{10}{|c|}{ Toughness } \\
\hline Fortune & $2.9 \mathrm{at}$ & $3.0 \mathrm{ds}$ & $4.4 \mathrm{ar}$ & $4.1 \mathrm{cq}$ & $5.5 \mathrm{bp}$ & & $4.5 \mathrm{cp}$ & $5.4 \mathrm{aq}$ & $3.6 \mathrm{dr}$ & $2.3 \mathrm{cs}$ & $0.8 \mathrm{dt}$ & \\
\hline Orbit & $3.6 \mathrm{bt}$ & $3.6 \mathrm{cs}$ & $3.8 \mathrm{ar}$ & $4.3 \mathrm{cq}$ & $9.3 \mathrm{ap}$ & & $5.3 \mathrm{bp}$ & $5.8 \mathrm{aq}$ & $4.6 \mathrm{cr}$ & $3.1 \mathrm{bs}$ & $3.0 \mathrm{ct}$ & \\
\hline BBL & $1.5 \mathrm{ct}$ & $3.9 \mathrm{bs}$ & $3.0 \mathrm{br}$ & $2.9 \mathrm{dq}$ & $3.4 \mathrm{cp}$ & $7.3 \mathrm{a}$ & $6.4 \mathrm{ap}$ & $4.5 \mathrm{cq}$ & $5.8 \mathrm{ar}$ & $5.5 \mathrm{ar}$ & $5.4 \mathrm{ar}$ & \\
\hline Corene & $2.9 \mathrm{at}$ & $5.3 \mathrm{as}$ & $4.6 \mathrm{ar}$ & $5.1 \mathrm{aq}$ & $5.6 \mathrm{bp}$ & & $6.3 \mathrm{ap}$ & $4.6 \mathrm{cq}$ & $4.9 \mathrm{br}$ & $3.4 \mathrm{bs}$ & $3.4 \mathrm{bt}$ & $1.5 \mathrm{~b}$ \\
\hline
\end{tabular}

Table 6. Preference Point as Linear Equation of $y=k(\Sigma$ pi,fi) $m$ or $\ln y=\ln k+m \ln (\Sigma$ pi,fi).

\begin{tabular}{|c|c|c|c|c|c|c|c|c|c|c|c|}
\hline & \multicolumn{3}{|c|}{ Equations } & \multicolumn{6}{c|}{$\ln \mathrm{y}=\ln \mathrm{c}+\mathrm{m} \ln \Sigma \mathrm{p}_{\mathrm{i}} \mathrm{t}_{\mathrm{i}}}$. \\
\hline Cultivar & $\ln \mathrm{k}$ & $\mathrm{m}$ & $\mathrm{r}$ & 160 & 170 & 180 & 190 & 200 & $210 \mathrm{c}$ & 220 & 230 \\
\hline Fortune & $55.6 \mathrm{~b}$ & $-10.2 \mathrm{a}$ & $0.90 \mathrm{a}$ & & & & $9.54 \mathrm{a}$ & $5.66 \mathrm{a}$ & $3.45 \mathrm{a}$ & $2.15 \mathrm{a}$ & $1.37 \mathrm{~b}$ \\
\hline Orbit & $57.6 \mathrm{~b}$ & $-10.8 \mathrm{a}$ & $0.94 \mathrm{a}$ & & $6.66 \mathrm{a}$ & $3.52 \mathrm{~b}$ & $1.99 \mathrm{~d}$ & $1.14 \mathrm{~d}$ & $0.67 \mathrm{c}$ & $0.41 \mathrm{~d}$ & $0.25 \mathrm{~d}$ \\
\hline BBL & $21.9 \mathrm{~d}$ & $-4.0 \mathrm{c}$ & $0.90 \mathrm{a} 3$ & $6.33 \mathrm{a}$ & $4.98 \mathrm{~b}$ & $3.97 \mathrm{a}$ & $3.21 \mathrm{c}$ & $2.62 \mathrm{c}$ & $2.16 \mathrm{~b}$ & $1.80 \mathrm{~b}$ & $151 \mathrm{a}$ \\
\hline Corene & $50.1 \mathrm{c}$ & $-9.2 \mathrm{~b}$ & $0.91 \mathrm{~b}$ & & & & $6.30 \mathrm{~b}$ & $3.93 \mathrm{~b}$ & $2.51 \mathrm{~b}$ & $1.64 \mathrm{c}$ & $1.09 \mathrm{c}$ \\
\hline
\end{tabular}

Table7. Bean Pod Growth and Sensory Properties, and Four Cultivars.

\begin{tabular}{|c|c|c|c|c|c|c|c|c|c|c|}
\hline Days & $<0.6$ & $7.6-8.8$ & 8.9-10.2 & $10.3-11.0$ & $>11$ & $<0.6$ & $7.6-8.8$ & 8.9-10.2 & 10.3-11.0 & $>11$ \\
\hline & \multicolumn{5}{|c|}{ Mealiness/ Orbit } & \multicolumn{5}{|c|}{ Toughness/ Orbit } \\
\hline 0 & $1.3 \mathrm{c}$ & $2.4 \mathrm{~d}$ & $4.4 \mathrm{~b}$ & $4.9 \mathrm{c}$ & $6.3 d$ & $2.7 \mathrm{a}$ & $5.4 \mathrm{a}$ & $5.6 \mathrm{~b}$ & $6.6 \mathrm{a}$ & $4.6 \mathrm{~b}$ \\
\hline 3 & $2.0 \mathrm{a}$ & $2.9 \mathrm{c}$ & $3.1 \mathrm{~d}$ & $4.1 \mathrm{e}$ & $6.3 \mathrm{~d}$ & $1.4 \mathrm{e}$ & $5.6 \mathrm{a}$ & $6.1 \mathrm{a}$ & $6.0 \mathrm{~b}$ & $5.3 \mathrm{a}$ \\
\hline 7 & $2.0 \mathrm{a}$ & $3.4 \mathrm{a}$ & $4.1 \mathrm{~b}$ & $4.6 \mathrm{~d}$ & $7.6 \mathrm{c}$ & $1.7 \mathrm{~d}$ & $2.3 \mathrm{~d}$ & $4.1 \mathrm{c}$ & $6.0 \mathrm{~b}$ & $2.4 \mathrm{~b}$ \\
\hline 10 & $2.1 \mathrm{a}$ & $1.9 \mathrm{e}$ & $3.6 \mathrm{~d}$ & $6.4 \mathrm{~b}$ & $8.1 \mathrm{~b}$ & $1.9 \mathrm{~b}$ & $4.3 \mathrm{~b}$ & $4.7 \mathrm{~b}$ & $3.4 \mathrm{~d}$ & $2.3 \mathrm{~d}$ \\
\hline 14 & $1.9 \mathrm{~b}$ & $3.1 \mathrm{~b}$ & $5.0 \mathrm{a}$ & $7.4 \mathrm{a}$ & $8.4 a$ & $1.8 \mathrm{c}$ & $3.1 \mathrm{e}$ & $3.4 \mathrm{~d}$ & $4.8 \mathrm{c}$ & $3.4 \mathrm{c}$ \\
\hline \multirow[t]{2}{*}{ Avg. } & $1.9 \mathrm{v}$ & $2.7 \mathrm{u}$ & $4.0 \mathrm{~s}$ & $5.5 q$ & $7.3 p$ & $1.9 \mathrm{r}$ & $4.1 \mathrm{~s}$ & $4.8 \mathrm{r}$ & $5.4 q$ & $3.6 \mathrm{t}$ \\
\hline & \multicolumn{5}{|c|}{ BBL } & \multicolumn{5}{|c|}{ BBL } \\
\hline 0 & $0.9 \mathrm{c}$ & $1.7 \mathrm{c}$ & $3.4 \mathrm{~b}$ & $4.9 \mathrm{c}$ & $5.7 \mathrm{~d}$ & $5.6 b$ & $5.4 \mathrm{~b}$ & $3.3 \mathrm{e}$ & $4.0 \mathrm{c}$ & $3.6 \mathrm{e}$ \\
\hline 5 & $1.3 \mathrm{~b}$ & $2.1 \mathrm{a}$ & $2.3 \mathrm{c}$ & $4.0 \mathrm{~d}$ & $5.1 \mathrm{e}$ & $2.7 \mathrm{~d}$ & $3.6 \mathrm{e}$ & $3.6 \mathrm{~d}$ & $4.9 \mathrm{~b}$ & $3.9 \mathrm{~d}$ \\
\hline 8 & $0.4 \mathrm{e}$ & $2.0 \mathrm{~b}$ & $3.7 \mathrm{a}$ & $5.1 \mathrm{~b}$ & $5.9 \mathrm{c}$ & $3.6 \mathrm{~d}$ & $4.4 \mathrm{~d}$ & $6.4 \mathrm{~b}$ & $3.7 \mathrm{~d}$ & $5.6 \mathrm{a}$ \\
\hline 12 & $0.7 \mathrm{~d}$ & $1.6 \mathrm{c}$ & $3.7 \mathrm{a}$ & $4.7 \mathrm{~b}$ & $6.9 \mathrm{~b}$ & $4.0 \mathrm{c}$ & $4.7 \mathrm{c}$ & $2.0 \mathrm{f}$ & $3.7 \mathrm{~d}$ & $2.4 \mathrm{f}$ \\
\hline 15 & $1.4 \mathrm{a}$ & $1.7 \mathrm{c}$ & $3.7 \mathrm{a}$ & $5.3 \mathrm{a}$ & $7.0 \mathrm{a}$ & $5.9 \mathrm{a}$ & $5.6 \mathrm{a}$ & $6.7 \mathrm{a}$ & $4.7 \mathrm{a}$ & $5.1 \mathrm{~b}$ \\
\hline \multirow[t]{2}{*}{ Avg } & $0.9 \mathrm{t}$ & $1.8 \mathrm{~s}$ & $3.4 \mathrm{r}$ & $4.8 \mathrm{q}$ & $6.1 \mathrm{p}$ & $4.4 \mathrm{r}$ & $4.7 q$ & $4.4 \mathrm{~s}$ & $4.2 \mathrm{t}$ & $4.1 \mathrm{c}$ \\
\hline & \multicolumn{5}{|c|}{ Corene } & \multicolumn{5}{|c|}{ Corene } \\
\hline 0 & 1.3 & $1.6 \mathrm{~b}$ & $4.7 \mathrm{a}$ & $4.7 \mathrm{c}$ & $7.7 \mathrm{c}$ & $6.1 \mathrm{c}$ & $5.1 \mathrm{~d}$ & $4.6 \mathrm{~d}$ & $3.7 \mathrm{~b}$ & $2.2 \mathrm{a}$ \\
\hline 3 & 0.9 & $1.9 \mathrm{a}$ & $3.0 \mathrm{~b}$ & $5.4 \mathrm{a}$ & $7.9 \mathrm{a}$ & $6.1 \mathrm{c}$ & $5.6 \mathrm{c}$ & $4.7 \mathrm{c}$ & $3.9 \mathrm{a}$ & $2.3 \mathrm{a}$ \\
\hline 7 & 1.3 & $1.9 \mathrm{a}$ & $2.4 \mathrm{c}$ & $5.3 \mathrm{~b}$ & $7.7 \mathrm{c}$ & $6.7 \mathrm{a}$ & $6.4 \mathrm{a}$ & $5.6 \mathrm{a}$ & $3.7 \mathrm{~b}$ & $2.1 \mathrm{a}$ \\
\hline \multirow[t]{2}{*}{ Avg } & $1.2 \mathrm{t}$ & $1.8 \mathrm{~s}$ & $3.4 \mathrm{r}$ & $5.1 \mathrm{q}$ & $7.8 \mathrm{p}$ & $6.3 q$ & $5.7 \mathrm{~s}$ & $5.0 \mathrm{p}$ & $3.8 \mathrm{bu}$ & $2.2 \mathrm{av}$ \\
\hline & \multicolumn{5}{|c|}{ Sweetness/ Orbit } & \multicolumn{5}{|c|}{ Preference/Orbit } \\
\hline 0 & $5.0 \mathrm{c}$ & $5.0 \mathrm{c}$ & $4.9 \mathrm{~b}$ & $4.3 \mathrm{c}$ & $4.0 \mathrm{~d}$ & $5.7 \mathrm{c}$ & $5.9 \mathrm{~b}$ & $3.7 \mathrm{e}$ & $3.3 \mathrm{c}$ & $2.3 b$ \\
\hline 3 & $6.4 \mathrm{a}$ & $5.3 b$ & $4.4 \mathrm{c}$ & $4.9 \mathrm{a}$ & $4.3 \mathrm{c}$ & $6.4 \mathrm{~b}$ & $4.6 \mathrm{~d}$ & $4.1 \mathrm{~d}$ & $3.9 \mathrm{~b}$ & $3.1 \mathrm{~b}$ \\
\hline 7 & $5.9 \mathrm{~b}$ & $5.9 \mathrm{a}$ & $5.6 a$ & $4.6 \mathrm{~b}$ & $4.7 \mathrm{a}$ & $7.0 \mathrm{a}$ & $5.4 \mathrm{c}$ & $5.4 \mathrm{a}$ & 3.2 & $3.4 \mathrm{a}$ \\
\hline 10 & $4.7 \mathrm{~d}$ & $5.1 \mathrm{~b}$ & $3.9 \mathrm{e}$ & $4.4 \mathrm{c}$ & $3.7 \mathrm{c}$ & $6.3 b$ & $5.7 b$ & $5.0 \mathrm{~b}$ & $4.0 \mathrm{a}$ & $2.7 \mathrm{c}$ \\
\hline 13 & $4.6 \mathrm{e}$ & $4.9 \mathrm{~d}$ & $4.0 \mathrm{~cd}$ & $3.8 \mathrm{~d}$ & $4.4 \mathrm{~b}$ & $6.5 b$ & $6.5 \mathrm{a}$ & $4.3 \mathrm{c}$ & $2.0 \mathrm{e}$ & $2.0 \mathrm{~d}$ \\
\hline \multirow[t]{2}{*}{ Avg. } & $5.3 a$ & $5.2 b$ & $4.6 \mathrm{c}$ & $4.4 \mathrm{~d}$ & $4.2 \mathrm{c}$ & $6.4 \mathrm{a}$ & $5.6 \mathrm{~b}$ & $4.5 \mathrm{c}$ & $3.3 \mathrm{~d}$ & $2.7 \mathrm{c}$ \\
\hline & \multicolumn{5}{|c|}{ BBL } & \multicolumn{5}{|c|}{ BBL } \\
\hline 0 & $5.7 \mathrm{~b}$ & $4.9 \mathrm{c}$ & $5.4 \mathrm{~b}$ & $4.0 \mathrm{~b}$ & $5.0 \mathrm{a}$ & $5.0 \mathrm{~b}$ & $4.6 \mathrm{~d}$ & $5.9 \mathrm{a}$ & $4.3 \mathrm{~b}$ & $3.7 \mathrm{~b}$ \\
\hline 3 & $5.1 \mathrm{c}$ & $5.7 \mathrm{a}$ & $5.3 \mathrm{a}$ & $4.3 \mathrm{a}$ & $3.9 \mathrm{c}$ & $6.0 \mathrm{a}$ & $6.3 \mathrm{~b}$ & $5.9 \mathrm{a}$ & $4.0 \mathrm{c}$ & $4.0 \mathrm{a}$ \\
\hline 7 & $5.3 \mathrm{c}$ & $4.9 \mathrm{c}$ & $4.6 \mathrm{c}$ & $4.0 \mathrm{c}$ & $3.6 \mathrm{~d}$ & $6.4 c$ & $5.7 \mathrm{c}$ & $4.4 \mathrm{c}$ & $4.0 \mathrm{c}$ & $3.0 \mathrm{c}$ \\
\hline 10 & $4.7 \mathrm{~d}$ & $4.9 \mathrm{c}$ & $3.9 \mathrm{~d}$ & $4.3 b$ & $4.0 \mathrm{~b}$ & $5.7 \mathrm{c}$ & $6.3 b$ & $4.7 b$ & $4.3 \mathrm{c}$ & $2.1 \mathrm{~d}$ \\
\hline 13 & $5.9 a$ & $5.3 b$ & $4.7 \mathrm{c}$ & $4.6 \mathrm{a}$ & $4.1 \mathrm{c}$ & $5.0 \mathrm{~b}$ & $6.4 a$ & $3.7 \mathrm{~d}$ & $3.6 \mathrm{c}$ & $3.0 \mathrm{c}$ \\
\hline \multirow[t]{2}{*}{ Avg. } & $5.3 b$ & $5.1 \mathrm{~b}$ & $4.8 \mathrm{c}$ & $4.2 \mathrm{~d}$ & $4.1 \mathrm{~d}$ & $5.6 \mathrm{~b}$ & $5.9 \mathrm{a}$ & $4.9 \mathrm{c}$ & 3.c & $3.2 \mathrm{c}$ \\
\hline & \multicolumn{5}{|c|}{ Corene } & \multicolumn{5}{|c|}{ Corene } \\
\hline 0 & $6.0 \mathrm{a}$ & $5.6 \mathrm{a}$ & $4.9 \mathrm{a}$ & $4.9 \mathrm{a}$ & $3.4 \mathrm{a}$ & $5.1 \mathrm{~b}$ & $4.6 \mathrm{~b}$ & $3.7 b$ & $2.2 \mathrm{a}$ & $2.2 \mathrm{a}$ \\
\hline 3 & $5.1 \mathrm{c}$ & $4.6 c$ & $4.4 \mathrm{~b}$ & $4.4 \mathrm{~b}$ & $3.4 \mathrm{a}$ & $5.6 \mathrm{a}$ & $4.7 \mathrm{a}$ & $3.9 \mathrm{a}$ & $2.3 \mathrm{a}$ & $2.3 a$ \\
\hline 7 & $5.6 b$ & $5.4 b$ & $4.9 \mathrm{a}$ & $3.4 \mathrm{c}$ & $3.3 \mathrm{a}$ & $5.6 \mathrm{a}$ & $4.7 \mathrm{a}$ & $3.9 \mathrm{a}$ & $2.3 \mathrm{a}$ & $2.2 \mathrm{a}$ \\
\hline Avg. & $5.6 p$ & $5.2 q$ & $4.9 \mathrm{r}$ & $4.2 \mathrm{~s}$ & $3.4 \mathrm{t}$ & $5.4 p$ & $4.7 q$ & $3.8 \mathrm{r}$ & $2.3 \mathrm{~s}$ & $2.3 \mathrm{~s}$ \\
\hline
\end{tabular}

Table8. Multiple Regression Coefficients for the Properties of Four Cultivars with Significances in $\Sigma$ pifi.

\begin{tabular}{|c|c|c|c|c|c|c|c|c|}
\hline & \multicolumn{3}{|c|}{ Regression coefficients } & \multicolumn{4}{c|}{ Effects of blanching } \\
\hline Cultivar & $\mathbf{b}_{\mathbf{0}}$ & $\mathbf{b}_{\mathbf{1}}$ & $\mathbf{b}_{\mathbf{3}}$ & $\mathbf{b}_{\mathbf{4}}$ & $\mathbf{F}$ & $\mathbf{l n} \mathbf{k}$ & Cons t. & $\mathbf{r}$ \\
\hline Fortune & 3.04 & $-0.20^{\mathrm{x}}$ & $\left.-0.11^{\mathrm{x}}\right)$ & $0.52^{\mathrm{x}}$ & $8.2^{\mathrm{x})}$ & $55.62 \mathrm{a}$ & $-10.17 \mathrm{c}$ & 0.90 \\
\hline
\end{tabular}




\begin{tabular}{|l|l|l|l|l|l|l|l|l|}
\hline Orbit & 3.03 & $0.07^{\mathrm{ns})}$ & $-0.35^{\mathrm{x})}$ & $0.66^{\mathrm{x})}$ & $27.6^{\mathrm{x})}$ & $57.57 \mathrm{a}$ & $-10.84 \mathrm{~d}$ & 0.94 \\
\hline BBL & 3.93 & $-0.21^{\mathrm{x})}$ & $-0.26^{\mathrm{x}}$ & $\left.0.57^{\mathrm{x}}\right)$ & $38.8^{\mathrm{x})}$ & $21.95 \mathrm{c}$ & $-3.96 \mathrm{a}$ & 0.93 \\
\hline Corene & 3.75 & $\left.-0.24^{\mathrm{x}}\right)$ & $0.21^{\mathrm{x})}$ & $0.70^{\mathrm{x}}$ & $25.5^{\mathrm{x}}$ & $50.00 \mathrm{~b}$ & $-9.19 \mathrm{~b}$ & 0.91 \\
\hline
\end{tabular}

Table9. Average Preference Points, Product Sums for Points, Percentage Pod Distribution.

\begin{tabular}{|c|c|c|c|c|c|c|c|c|c|c|c|c|}
\hline Cultivar & \multicolumn{4}{|c|}{ Bean pod diameter, mm } & \multicolumn{4}{c|}{ Product sums } & Equation & r \\
\hline & $<\mathbf{7 . 5}$ & $\mathbf{7 . 6 - 8 . 8}$ & $\mathbf{8 . 9 - 1 0 . 3}$ & $\mathbf{1 0 . 3 - 1 1 . 0}$ & $\mathbf{1 1 . 0}$ & $\mathbf{0}$ & $\mathbf{3}$ & $\mathbf{7}$ & $\mathbf{1 0}$ & $\mathbf{1 4}$ & & \\
\hline Orbit & $6.7 \mathrm{~b}$ & $5.6 \mathrm{a}$ & $4.1 \mathrm{a}$ & $3.1 \mathrm{~b}$ & $2.8 \mathrm{c}$ & $4.09 \mathrm{~b}$ & $4.01 \mathrm{~b}$ & $3.60 \mathrm{c}$ & $3.56 \mathrm{c}$ & $3.40 \mathrm{~b}$ & $\begin{array}{c}\ln \mathrm{Q}=1.41- \\
014 \mathrm{days}\end{array}$ & $\begin{array}{c}0 . \\
97 \\
\end{array}$ \\
\hline BBL & $6.2 \mathrm{c}$ & $5.5 \mathrm{a}$ & $4.4 \mathrm{a}$ & $3.7 \mathrm{a}$ & $3.5 \mathrm{a}$ & $5.35 \mathrm{a}$ & $4.61 \mathrm{a}$ & $4.41 \mathrm{~b}$ & $4.09 \mathrm{~b}$ & $3.17 \mathrm{c}$ & $\begin{array}{c}\ln \mathrm{Q}=1.70- \\
.031 \mathrm{days}\end{array}$ & $\begin{array}{c}0 . \\
95\end{array}$ \\
\hline Corene & $6.9 \mathrm{a}$ & $5.8 \mathrm{a}$ & $4.2 \mathrm{a}$ & $3.3 \mathrm{~b}$ & $3.0 \mathrm{~b}$ & & & $5.07 \mathrm{a}$ & $4.76 \mathrm{a}$ & 4.52 & $\begin{array}{c}\ln \mathrm{Q}=1.62- \\
.016 \mathrm{days}\end{array}$ & $\begin{array}{c}0 . \\
99\end{array}$ \\
\hline
\end{tabular}

Table10. Cultivars, Area Size, Plant Density and Degree Days from Sowing to Picking.

\begin{tabular}{|c|c|c|c|c|c|c|c|c|c|c|}
\hline Cultivar & ha & Sowing & Picking & No & \multicolumn{5}{|c|}{ Degree days ${ }^{\circ} \mathrm{C}$} & Increases \\
\hline Carobell & 11.0 & $22^{\text {nd }}$ May & $17-23^{\text {rd }}$ Aug & 20.3 & $810 \mathrm{c}$ & $866 b$ & $922 b$ & $949 b$ & $993 b$ & $183 a$ \\
\hline Solist & 6.6 & $24^{\text {th }}$ " & $25-28^{\text {th }}$ Aug & 12.1 & $934 a$ & $970 a$ & $998 \mathrm{a}$ & $1020 \mathrm{a}$ & $1046 a$ & $112 d$ \\
\hline " & 7.7 & $26^{\text {th }}$ & 6 & 16.0 & $836 \mathrm{c}$ & $880 b$ & $916 b$ & $951 \mathrm{~b}$ & $979 \mathrm{c}$ & $143 b$ \\
\hline Ludibell & 7.7 & $3^{\text {rd }}$ June & $28^{\text {th }}-30^{\text {th }} \mathrm{Aug}$ & 17.7 & $788 \mathrm{~d}$ & $844 b$ & $884 c$ & $920 \mathrm{~b}$ & $930 \mathrm{~b}$ & $142 \mathrm{c}$ \\
\hline 6 & 2.2 & $12^{\text {th }}$ “ & $4^{\text {th }}-5^{\text {th }}$ Sep & 17.7 & $777 \mathrm{~d}$ & $814 \mathrm{~b}$ & $830 \mathrm{c}$ & $844 c$ & $871 d$ & $94 \mathrm{e}$ \\
\hline Corene & 3.3 & $20^{\text {th }}$ “ & $11^{\text {th }}-32^{\text {th }}$ Sep & 12.1 & 761d & $776 b$ & $803 c$ & $819 c$ & $826 \mathrm{~d}$ & $65 g$ \\
\hline Orbit & 11.4 & $16^{\text {th } "}$ & $13^{\text {th }}-14^{\text {th }}$ Sep & 14.1 & $791 d$ & $806 \mathrm{~b}$ & $839 \mathrm{c}$ & $855 \mathrm{~d}$ & $870 \mathrm{~d}$ & $79 f$ \\
\hline 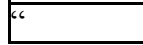 & 7.4 & $19^{\text {th } ~ “ ~}$ & $18^{\text {th }}-19^{\text {th }}$ Sep & 13.5 & $764 d$ & $779 \mathrm{~b}$ & $812 \mathrm{c}$ & $828 \mathrm{e}$ & $843 d$ & $79 \mathrm{f}$ \\
\hline
\end{tabular}

Table11. Pod Yield, Total Dry Matter and Alcohol Insoluble Solids versus Degree Days during the Picking Time for the Five Cultivars (Cons. = Constant; Reg = Regression Coefficient).

\begin{tabular}{|c|c|c|c|c|c|c|c|c|c|c|c|c|}
\hline & \multicolumn{3}{|c|}{ Yield, kg ha' } & \multicolumn{3}{|c|}{ Dry matter, kg ha-1 } & \multicolumn{3}{|c|}{ AIS, kg ha-1 } & \multicolumn{3}{|c|}{ Chlorophyll, mg kg-1 } \\
\hline Cultivar & Cons. & Reg co & $\mathbf{r}$ & Cons & Reg co & $\mathbf{r}$ & Cons. & Reg co & $\mathbf{r}$ & Cons. & Reg co & $\mathbf{r}$ \\
\hline Solist & $2.93 \mathrm{~d}$ & $0.046 \mathrm{c}$ & 0.98 & $315 c$ & $8.06 \mathrm{c}$ & 0.99 & $176.7 \mathrm{~b}$ & $5.30 \mathrm{~b}$ & 0.99 & 6.78 & $-0.052 \mathrm{a}$ & 0.99 \\
\hline " & $3.87 \mathrm{~b}$ & $0.064 \mathrm{c}$ & 1.00 & $316 \mathrm{c}$ & $12.28 \mathrm{a}$ & 0.98 & $129.3 \mathrm{c}$ & $7.74 a$ & 0.98 & $7.03 \mathrm{a}$ & $-0.052 \mathrm{a}$ & 0.98 \\
\hline Ludibell & $3.70 \mathrm{~b}$ & $0.046 \mathrm{c}$ & 0.99 & $415 b$ & $7.76 \mathrm{~d}$ & 1.00 & $240.2 \mathrm{a}$ & $5.38 \mathrm{~b}$ & 1.00 & $7.09 \mathrm{a}$ & $-0.003 a$ & 0.79 \\
\hline “" & $4.40 \mathrm{~d}$ & $0.067 \mathrm{c}$ & 1.00 & $507 a$ & $8.15 \mathrm{c}$ & 1.00 & $221.5 \mathrm{a}$ & $5.24 b$ & 0.99 & $7.44 a$ & $-0.007 \mathrm{a}$ & 0.97 \\
\hline Corene & $2.81 \mathrm{~d}$ & $0.077 \mathrm{~b}$ & 1.00 & $274 d$ & $8.50 \mathrm{c}$ & 0.99 & $175.7 \mathrm{~b}$ & $4.26 \mathrm{c}$ & 0.91 & $7.12 \mathrm{a}$ & $-0.005 a$ & 0.92 \\
\hline Orbit & $3.39 \mathrm{c}$ & $0.083 \mathrm{a}$ & 1.00 & $282 d$ & $9.54 \mathrm{~b}$ & 0.99 & $99.9 \mathrm{~d}$ & $5.35 b$ & 0.98 & $7.53 \mathrm{a}$ & $-0.009 a$ & 0.95 \\
\hline " & $2.96 \mathrm{~d}$ & $0.054 \mathrm{c}$ & 1.00 & $272 d$ & $6.11 \mathrm{e}$ & 1.00 & $121.9 \mathrm{c}$ & $3.75 \mathrm{~d}$ & 1.00 & $7.24 a$ & $-0.007 \mathrm{a}$ & 0.93 \\
\hline
\end{tabular}

Table12. Cultivars, Degree Days, Pod Diameter for Seven Cultivars.

\begin{tabular}{|c|c|c|c|c|c|c|c|c|c|c|c|c|c|}
\hline \multirow[t]{2}{*}{ Cultivar } & \multirow[b]{2}{*}{ Ddg. } & \multirow[b]{2}{*}{$<7$} & \multicolumn{11}{|c|}{ Pod diameter, mm } \\
\hline & & & $7.1-8.9$ & $9.0-11.0$ & $>11.0$ & t ha-1 $^{-1}$ & & Dgd. & $<7$ & $7.1-8.9$ & $9-11$ & $>11$ & t ha' \\
\hline Carobell & 0 & $32.8 \mathrm{~b}$ & $37.5 \mathrm{a}$ & $26.92 c$ & $2.76 \mathrm{~d}$ & $5.8 \mathrm{~d}$ & Ludibell & 0 & 93.19a & $6.8 \mathrm{e}$ & - & - & $4.5 \mathrm{a}$ \\
\hline “" & 56 & $32.5 b$ & $15.2 \mathrm{~b}$ & $31.2 \mathrm{a}$ & $21.1 \mathrm{c}$ & $6.9 \mathrm{c}$ & “ & 37 & $87.03 \mathrm{~b}$ & $13.3 \mathrm{~d}$ & - & - & $6.5 b$ \\
\hline “6 & 83 & 38.8 & $8.1 d$ & $27.1 \mathrm{~b}$ & $26.0 \mathrm{~b}$ & $8.3 \mathrm{a}$ & “ & 53 & $45.22 \mathrm{c}$ & $54.8 \mathrm{c}$ & - & - & $8.1 \mathrm{c}$ \\
\hline “" & 127 & $33.3 \mathrm{~b}$ & $9.4 \mathrm{c}$ & $20.0 \mathrm{c}$ & $37.3 \mathrm{a}$ & $7.7 \mathrm{~b}$ & “" & 68 & $34.6 \mathrm{~d}$ & $65.0 \mathrm{~b}$ & - & - & $9.1 \mathrm{~b}$ \\
\hline \begin{tabular}{|l} 
Solist \\
\end{tabular} & 0 & $45.2 \mathrm{~b}$ & $52.1 \mathrm{f}$ & $2.7 \mathrm{e}$ & - & $2.8 \mathrm{f}$ & “ & 95 & $20.8 \mathrm{e}$ & $78.3 \mathrm{a}$ & $1.0 \mathrm{a}$ & - & $10.7 \mathrm{a}$ \\
\hline “ & 20 & $59.3 \mathrm{a}$ & $59.3 \mathrm{~d}$ & $9.5 \mathrm{~d}$ & - & $5.3 \mathrm{~d}$ & Corene & 0 & $50.0 \mathrm{a}$ & $47.3 \mathrm{a}$ & $2.8 \mathrm{f}$ & - & $2.9 \mathrm{f}$ \\
\hline “" & 56 & $34.0 \mathrm{c}$ & $54.7 \mathrm{e}$ & $11.3 \mathrm{c}$ & - & $6.1 \mathrm{c}$ & "“ & 16 & $26.6 \mathrm{~b}$ & $37.1 \mathrm{~b}$ & $37.4 \mathrm{e}$ & - & $4.2 \mathrm{e}$ \\
\hline “" & 84 & $26 . d$ & $62.1 \mathrm{c}$ & $12.4 \mathrm{~b}$ & & $6.1 \mathrm{c}$ & “ & 31 & $19.6 \mathrm{c}$ & $36.6 \mathrm{~b}$ & $43.8 \mathrm{~d}$ & - & $4.9 \mathrm{~d}$ \\
\hline “6 & 106 & $19.9 \mathrm{e}$ & $66.2 b$ & $12.8 \mathrm{~b}$ & 1.1 & $8.5 b$ & “" & 58 & $12.8 \mathrm{~d}$ & $24.7 \mathrm{e}$ & $62.2 b$ & $0.3 \mathrm{c}$ & $7.1 \mathrm{c}$ \\
\hline “6 & 132 & $11.9 \mathrm{f}$ & $73.5 a$ & $14.61 \mathrm{a}$ & - & $8.8 \mathrm{a}$ & “ & 74 & $8.5 f$ & $22.8 \mathrm{~d}$ & $67.0 \mathrm{a}$ & $1.7 \mathrm{~b}$ & $8.7 b$ \\
\hline Solist & 0 & $77.9 \mathrm{a}$ & $22.1 \mathrm{e}$ & - & - & $3.9 \mathrm{e}$ & “6 & 81 & $9.08 \mathrm{e}$ & $35.6 \mathrm{c}$ & $52.4 \mathrm{c}$ & $2.9 \mathrm{a}$ & 9.1a \\
\hline "6 & 45 & $55.9 \mathrm{~b}$ & $44.1 d$ & - & - & $6.4 \mathrm{~d}$ & Ludibell & 0 & $92.7 \mathrm{a}$ & $7.3 \mathrm{e}$ & - & - & 3.7 \\
\hline "“ & 80 & $23.0 \mathrm{~d}$ & $75.0 \mathrm{a}$ & $2.1 \mathrm{a}$ & - & $9.3 c$ & “ & 56 & $85.0 \mathrm{~b}$ & $14.0 \mathrm{~d}$ & $1.1 \mathrm{c}$ & & 5.9 \\
\hline "“ & 116 & $27.1 \mathrm{c}$ & $64.8 \mathrm{c}$ & $8.0 \mathrm{~b}$ & - . & $11.5 \mathrm{~b}$ & “ & 95 & $70.3 c$ & $29.7 \mathrm{c}$ & - & & 8.1 \\
\hline \multirow[t]{2}{*}{6} & 144 & $13.8 \mathrm{e}$ & $69.3 b$ & $17.0 \mathrm{c}$ & - & 12.8 & “ & 132 & $43.8 \mathrm{~d}$ & $55.3 b$ & $1.0 \mathrm{~b}$ & & 9.0 \\
\hline & & & & & & & “ & 142 & $18.6 \mathrm{e}$ & $78.3 \mathrm{a}$ & $3.1 \mathrm{a}$ & - & 8.3 \\
\hline Corene & 0 & $50.0 \mathrm{a}$ & $47.2 \mathrm{a}$ & $2.81 \mathrm{f}$ & - & 2.9 & Orbit & Of & 80.8 & $17.7 \mathrm{e}$ & 1.44 & 0 & 3.5 \\
\hline "“ & 16 & $25.6 \mathrm{~b}$ & $37.1 \mathrm{~b}$ & $37.4 \mathrm{e}$ & & 4.2 & “ & $36 e$ & 49.7 & 30.1 & 20.2 & 0 & 6.3 \\
\hline "، & 31 & $19.6 \mathrm{c}$ & $36.6 \mathrm{~b}$ & $43.8 \mathrm{~d}$ & - & 4.9 & "، & $50 \mathrm{~d}$ & 45.4 & 35.23 & 18.8 & 0.6 & 7.5 \\
\hline " & 58 & $12.8 \mathrm{~d}$ & $24.7 \mathrm{c}$ & $43.8 \mathrm{c}$ & $0.3 \mathrm{c}$ & 7.1 & “" & $84 c$ & 26.1 & 35.7 & 34.9 & 3.3 & 10.6 \\
\hline "“ & 74 & $8.5 \mathrm{e}$ & $22.8 \mathrm{e}$ & $62.2 a$ & $1.7 \mathrm{~b}$ & 8.7 & “" & $100 \mathrm{~b}$ & 19.7 & 37.3 & 38.8 & 4.2 & 11.7 \\
\hline "6 & 81 & 9.1f & $35.6 \mathrm{~d}$ & $52.4 b$ & $2.9 \mathrm{a}$ & 9.1 & “ & $115 \mathrm{a}$ & 17.1 & 22.6 & 56.1 & 4.2 & $12.9 \mathrm{a}$ \\
\hline
\end{tabular}


\begin{tabular}{|l|l|l|l|l|l|l|l|}
\hline Orbit & & & & $1.4 \mathrm{f}$ & - & $3.5 \mathrm{f}$ \\
\hline$“$ & 36 & & $30.2 \mathrm{c}$ & $20.2 \mathrm{~g}$ & - & $6.3 \mathrm{~g}$ & \\
\hline
\end{tabular}

Table13. Size Distribution and Texture Measured Using a Tenderometer.

\begin{tabular}{|l|l|l|l|l|l|l|l|l|l|l|}
\hline Days & \multicolumn{9}{|c|}{ BBL } & \multicolumn{5}{c|}{ Orbit } \\
\hline & $<\mathbf{7 . 6}$ & $\mathbf{7 . 6 - 8 . 8}$ & $\mathbf{8 . 9 - 1 0 . 2}$ & $\mathbf{1 0 . 3 - 1 1 . 0}$ & $>\mathbf{1 1 . 0}$ & $<7.6$ & $\mathbf{7 . 6 - 8 . 8}$ & $\mathbf{8 . 9 - 1 0 . 2}$ & $\mathbf{1 0 . 3 - 1 1 . 0}$ & $>\mathbf{1 1 . 0}$ \\
\hline 1 & $185 \mathrm{a}$ & $181 \mathrm{a}$ & $181 \mathrm{a}$ & $181 \mathrm{a}$ & $190 \mathrm{~b}$ & $180 \mathrm{a}$ & $155 \mathrm{a}$ & $160 \mathrm{a}$ & $153 \mathrm{a}$ & $169 \mathrm{a}$ \\
\hline 5 & $181 \mathrm{a}$ & $187 \mathrm{~b}$ & $183 \mathrm{a}$ & $183 \mathrm{a}$ & $187 \mathrm{a}$ & $179 \mathrm{a}$ & $165 \mathrm{~b}$ & $172 \mathrm{~b}$ & $162 \mathrm{~b}$ & $169 \mathrm{a}$ \\
\hline 8 & $181 \mathrm{a}$ & $183 \mathrm{a}$ & $187 \mathrm{c}$ & $189 \mathrm{~b}$ & $187 \mathrm{a}$ & $184 \mathrm{~b}$ & $178 \mathrm{c}$ & $197 \mathrm{c}$ & $187 \mathrm{c}$ & $181 \mathrm{~b}$ \\
\hline 12 & $181 \mathrm{a}$ & $183 \mathrm{a}$ & $184 \mathrm{~b}$ & $194 \mathrm{c}$ & $197 \mathrm{c}$ & $191 \mathrm{c}$ & $197 \mathrm{~d}$ & $205 \mathrm{~d}$ & $197 \mathrm{~d}$ & $204 \mathrm{c}$ \\
\hline 15 & $190 \mathrm{~b}$ & $189 \mathrm{~b}$ & $185 \mathrm{~b}$ & $192 \mathrm{~d}$ & $199 \mathrm{c}$ & $197 \mathrm{~d}$ & $205 \mathrm{e}$ & $214 \mathrm{e}$ & $215 \mathrm{e}$ & $225 \mathrm{~d}$ \\
\hline \multicolumn{8}{|c|}{ BBL, mm } \\
\hline 1 & $43.0 \mathrm{a}$ & $24.2 \mathrm{a}$ & $21.6 \mathrm{a}$ & $7.5 \mathrm{c}$ & $3.7 \mathrm{e}$ & $12.7 \mathrm{a}$ & $13.7 \mathrm{a}$ & $26.1 \mathrm{c}$ & $25.2 \mathrm{c}$ & $22.3 \mathrm{e}$ \\
\hline 5 & $24.2 \mathrm{~b}$ & $18.0 \mathrm{~b}$ & $21.1 \mathrm{a}$ & $22.9 \mathrm{~b}$ & $14.3 \mathrm{~d}$ & $9.5 \mathrm{~b}$ & $12.0 \mathrm{~b}$ & $33.5 \mathrm{a}$ & $22.5 \mathrm{~d}$ & $22.5 \mathrm{~d}$ \\
\hline 8 & $13.7 \mathrm{c}$ & $10.9 \mathrm{c}$ & $22.0 \mathrm{~b}$ & $21.4 \mathrm{~b}$ & $22.0 \mathrm{c}$ & $4.5 \mathrm{c}$ & $5.4 \mathrm{c}$ & $29.7 \mathrm{~b}$ & $28.2 \mathrm{~b}$ & $32.2 \mathrm{c}$ \\
\hline 12 & $6.4 \mathrm{~d}$ & $8.3 \mathrm{~d}$ & $22.5 \mathrm{c}$ & $21.6 \mathrm{~b}$ & $41.1 \mathrm{~b}$ & $5.7 \mathrm{~d}$ & $4.9 \mathrm{~d}$ & $23.9 \mathrm{~d}$ & $29.2 \mathrm{a}$ & $36.3 \mathrm{~b}$ \\
\hline 15 & $5.0 \mathrm{e}$ & $5.6 \mathrm{e}$ & $20.5 \mathrm{~d}$ & $22.4 \mathrm{a}$ & $46.5 \mathrm{a}$ & $2.9 \mathrm{e}$ & $7.2 \mathrm{e}$ & $16.0 \mathrm{e}$ & $26.8 \mathrm{a}$ & $47.1 \mathrm{a}$ \\
\hline
\end{tabular}

Table14. Contents of Alcohol Insoluble Dry Matter, Total Dry Matter, Sugars and Chlorophyll.

\begin{tabular}{|c|c|c|c|c|c|c|c|c|}
\hline Size, $\mathbf{m m}$ & $\begin{array}{c}\text { AIS } \\
\text { g } 100 \mathrm{~g}^{-1}\end{array}$ & 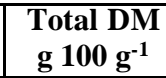 & $\begin{array}{c}\text { Sugar } \\
\text { g } 100 \mathrm{~g}^{-1}\end{array}$ & 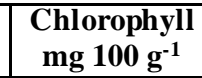 & $\begin{array}{c}\text { AIS } \\
\text { g } 100 \mathrm{~g}^{-1}\end{array}$ & 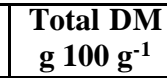 & $\begin{array}{c}\text { Sugar } \\
\text { g } 100 \mathrm{~g}^{-1}\end{array}$ & $\begin{array}{c}\text { Chlorophyll } \\
{\text { mg } 100 \mathrm{~g}^{-1}}\end{array}$ \\
\hline & \multicolumn{4}{|l|}{$\mathrm{BBL}$} & \multicolumn{4}{|l|}{\begin{tabular}{|l|} 
Orbit \\
\end{tabular}} \\
\hline$<7.5$ & $3.7 \mathrm{e}$ & $8.3 c$ & $2.4 \mathrm{~b}$ & $31.7 \mathrm{~d}$ & $4.8 \mathrm{e}$ & $9.8 \mathrm{~d}$ & $1.6 \mathrm{~b}$ & $43.8 \mathrm{~d}$ \\
\hline $7.5-8.8$ & $4.2 d$ & $9.4 \mathrm{~b}$ & $2.8 \mathrm{a}$ & $41.1 \mathrm{c}$ & $5.7 d$ & $11.6 \mathrm{c}$ & $1.7 \mathrm{a}$ & $49.1 \mathrm{c}$ \\
\hline $8.9-10.2$ & $5.2 b$ & $11.0 \mathrm{a}$ & $2.9 \mathrm{a}$ & $45.9 \mathrm{~b}$ & $8.5 \mathrm{c}$ & $14.5 b$ & $1.4 \mathrm{c}$ & $70.4 a$ \\
\hline $10.3-11.0$ & $5.2 \mathrm{c}$ & $11.0 \mathrm{a}$ & $2.9 \mathrm{a}$ & $45.9 \mathrm{~b}$ & $9.0 \mathrm{~b}$ & $14.9 \mathrm{~b}$ & $1.6 \mathrm{~b}$ & $62.6 \mathrm{c}$ \\
\hline$>11$ & $5.6 \mathrm{a}$ & $11.2 \mathrm{a}$ & $2.9 \mathrm{a}$ & $51.3 \mathrm{a}$ & $9.6 \mathrm{a}$ & $16.1 \mathrm{a}$ & $1.6 \mathrm{~b}$ & $66.1 \mathrm{~b}$ \\
\hline
\end{tabular}

Table15. Pod Weight and Contents of Sugars and Inositol in Four Cultivars.

\begin{tabular}{|c|c|c|c|c|c|}
\hline $\begin{array}{c}\text { Diameter } \\
\text { mm }\end{array}$ & $\begin{array}{c}\text { Pod weight } \\
\text { g } 100 \text { g. }^{-1}\end{array}$ & $\begin{array}{l}\text { Fructose } \\
\text { g } 100 \mathrm{~g}^{-1}\end{array}$ & $\begin{array}{c}\text { Glucose } \\
\text { g } 100 \mathrm{~g}^{-1}\end{array}$ & $\begin{array}{l}\text { Sucrose } \\
\text { g } 100 \mathrm{~g}^{-1}\end{array}$ & $\begin{array}{l}\text { Inositol } \\
{\text { g } 100^{-1}}\end{array}$ \\
\hline & & & Carobell & & \\
\hline$<7$ & $1.28 \mathrm{c}$ & $1.42 \mathrm{a}$ & $0.66 \mathrm{a}$ & $0.51 \mathrm{c}$ & $0.49 a$ \\
\hline 7-8.9 & $3.15 b$ & $0.88 b$ & $0.23 b$ & $0.80 \mathrm{~b}$ & $0.43 c$ \\
\hline \multirow[t]{2}{*}{ 9-11 } & $3.66 a$ & $0.75 c$ & $0.16 \mathrm{c}$ & $1.25 \mathrm{a}$ & $0.45 b$ \\
\hline & & & Ludibell & & \\
\hline$<7$ & $0.98 \mathrm{c}$ & $0.89 a$ & $0.57 \mathrm{a}$ & $0.44 \mathrm{a}$ & $0.30 \mathrm{c}$ \\
\hline $7-8.9$ & $2.63 b$ & $0.73 b$ & $0.31 \mathrm{~b}$ & $0.26 \mathrm{~b}$ & $0.74 a$ \\
\hline \multirow[t]{2}{*}{ 9-11 } & $3.58 \mathrm{a}$ & $0.29 \mathrm{c}$ & $0.12 c$ & $0.10 \mathrm{c}$ & $0.52 b$ \\
\hline & & & Corene & & \\
\hline$<7$ & $0.85 a$ & $0.77 b$ & $1.19 \mathrm{~b}$ & $0.03 c$ & $0.10 \mathrm{a}$ \\
\hline $7-8.9$ & $4.12 b$ & $1.03 \mathrm{a}$ & $1.23 \mathrm{a}$ & $0.02 b$ & $0.05 c$ \\
\hline \multirow[t]{2}{*}{ 9-11 } & $6.38 c$ & $1.03 \mathrm{a}$ & $1.08 \mathrm{c}$ & $1.32 \mathrm{a}$ & $0.08 \mathrm{~b}$ \\
\hline & & & Orbit & & \\
\hline$<7$ & $1.10 \mathrm{a}$ & $1.32 \mathrm{a}$ & $0.09 \mathrm{c}$ & $0.05 \mathrm{~d}$ & $0.08 \mathrm{a}$ \\
\hline $7-8.9$ & $1.09 a$ & $1.26 \mathrm{a}$ & $0.08 \mathrm{c}$ & $0.08 \mathrm{c}$ & $0.06 a$ \\
\hline 9-11 & $1.10 \mathrm{a}$ & $0.97 \mathrm{a}$ & $0.25 b$ & $0.25 b$ & $0.06 a$ \\
\hline
\end{tabular}

Table16. Total Yield and Total Dry Matter. Reg co = Regression Coefficient.

\begin{tabular}{|c|c|c|c|c|c|c|c|}
\hline Field & Cultivar & Constant & Reg, co & $\mathbf{r}$ & Constant, $b$ & Reg co & $\mathbf{r}$ \\
\hline & \multicolumn{4}{|c|}{ Total yield $\mathrm{t} \mathrm{ha} \mathrm{h}^{-1}$} & \multicolumn{3}{|c|}{ Dry matter kg ha-1 } \\
\hline 2 & Solist & $2.93 \mathrm{c}$ & $0.0457 \mathrm{f}$ & 0.979 & $8.06 \mathrm{~d}$ & $315.0 \mathrm{c}$ & 0.989 \\
\hline 3 & “6 & $3.87 \mathrm{~b}$ & $0.0638 \mathrm{~d}$ & 0.996 & $12.28 \mathrm{a}$ & $316.4 \mathrm{c}$ & 0.984 \\
\hline 4 & Ludibell & $3.70 \mathrm{~b}$ & $0.0461 \mathrm{f}$ & 0.992 & $7.78 \mathrm{e}$ & $415.2 \mathrm{ab}$ & 0.996 \\
\hline 5 & “ & $4.40 \mathrm{a}$ & $0.0671 \mathrm{c}$ & 0.996 & $8.15 \mathrm{c}$ & $507.9 \mathrm{a}$ & 0.997 \\
\hline 7 & Corene & $2.81 \mathrm{c}$ & $0.0766 b$ & 0.996 & 8.30 & $274.7 \mathrm{e}$ & 0.990 \\
\hline 8 & Orbit & $3.39 \mathrm{~b}$ & $0.0832 \mathrm{a}$ & 0.990 & $9.54 b$ & $282.2 \mathrm{~d}$ & 0.992 \\
\hline 9 & 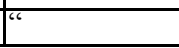 & $2.96 \mathrm{c}$ & $0.0538 \mathrm{e}$ & 0.999 & $6.11 \mathrm{f}$ & $272.0 \mathrm{e}$ & 0.996 \\
\hline
\end{tabular}

Table17. Total Yield, Alcohol Insoluble Dry Matter and Chlorophyll versus AIS and Chlorophyll Degree Days.

\begin{tabular}{|l|l|l|l|l|l|l|l|}
\hline Field & Cultivar & Constant & Reg co & r & Constant & m & R \\
\hline & & \multicolumn{2}{|c|}{ AIS } & & \multicolumn{3}{c|}{ Chlorophyll } \\
\hline 2 & Solist & $5.30 \mathrm{~b}$ & $176.7 \mathrm{c}$ & 0.987 & $6.78 \mathrm{~b}$ & $-0.052 \mathrm{c}$ & 0.987 \\
\hline
\end{tabular}




\begin{tabular}{|l|l|l|l|l|l|l|l|}
\hline 3 & "“ & $7.74 \mathrm{a}$ & $129.2 \mathrm{~d}$ & 0.978 & $7.03 \mathrm{a}$ & $-0.052 \mathrm{~b}$ & 0.981 \\
\hline 4 & Ludibell & $5.38 \mathrm{~b}$ & $221.5 \mathrm{a}$ & 0.995 & $7.09 \mathrm{a}$ & $-0.0031 \mathrm{~d}$ & 0.789 \\
\hline 5 & “" & $5.24 \mathrm{~b}$ & $198.6 \mathrm{~b}$ & 0.990 & $7.44 \mathrm{a}$ & $-0.0073 \mathrm{~b}$ & 0.973 \\
\hline 5 & Corene & $4.26 \mathrm{c}$ & $175.7 \mathrm{c}$ & 0.951 & $7.12 \mathrm{a}$ & $-0.0053 \mathrm{~b}$ & 0.922 \\
\hline 7 & Orbit & $5.35 \mathrm{~b}$ & $99.9 \mathrm{~g}$ & 0.983 & $7.53 \mathrm{a}$ & $-0.0093 \mathrm{a}$ & 0.949 \\
\hline 8 & " & $3.75 \mathrm{~d}$ & $121.9 \mathrm{f}$ & 0.995 & $7.24 \mathrm{a}$ & $-0.0070 \mathrm{~b}$ & 0.934 \\
\hline
\end{tabular}

Table18. Descriptions of Cultivars and Experimental Data.

\begin{tabular}{|c|c|c|c|c|c|c|c|c|c|c|}
\hline & Cultivar & ha $^{-1}$ & Row, cm & Picking & Sowing & $\mathbf{n}$ & ha $^{-1}$ & Plants, $m$ & Stddev & Std. mean \\
\hline 1 & Carobell & $11.0 \mathrm{a}$ & 50 & May 22 & 17-23 Aug & 4 & 11.0 & $8-33 e$ & $4.86 \mathrm{ab}$ & $0.49 \mathrm{~b}$ \\
\hline 2 & Solist & $6.6 \mathrm{~d}$ & 6 & 4 & $16-28$ " & 6 & 6.6 & $3-19 f$ & $3.20 \mathrm{~d}$ & $0.32 \mathrm{c}$ \\
\hline 3 & "6 & $7.1 \mathrm{c}$ & “ & 26 & $11-23$ “ & 5 & 7.7 & $6-27 b$ & $4.28 \mathrm{a}$ & $0.43 b$ \\
\hline 4 & Ludibel & $7.7 \mathrm{~b}$ & "6 & Jun 3 & $8-29 "$ & 5 & 7.7 & $9-28 a$ & $3.76 \mathrm{~b}$ & $0.83 a$ \\
\hline 5 & 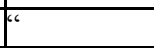 & $2.2 \mathrm{~h}$ & "“ & " 12 & $24-9$ " & 5 & 2.2 & $8-24 b$ & $3.26 \mathrm{e}$ & $0.33 c$ \\
\hline 6 & Corene & $4.2 \mathrm{~g}$ & " & " 16 & $23-30 "$ & 3 & 4.2 & $6-26 b$ & $3.97 \mathrm{~b}$ & $0.40 \mathrm{~b}$ \\
\hline 7 & 6 & $3.3 \mathrm{f}$ & “6 & " 20 & $28-30$ “" & 6 & 3.3 & $3-24 c$ & $3.36 \mathrm{c}$ & $0.34 \mathrm{c}$ \\
\hline 8 & Orbit & $11.4 \mathrm{a}$ & 63 & " 16 & $11-13^{\prime 6}$ & 6 & 11.4 & $3-24$ & $2.23 \mathrm{e}$ & $0.22 \mathrm{~d}$ \\
\hline 9 & 6 & $7.4 \mathrm{~b}$ & 63 & " 19 & $13-14$ “" & 5 & 7.4 & $9-19 d$ & $2.23 \mathrm{e}$ & $0.22 \mathrm{~d}$ \\
\hline 10 & Corene & $5.5 \mathrm{e}$ & 50 & " 19 & $8-11^{\prime \prime}$ & 5 & 5.5 & $9-20 d$ & $3.59 \mathrm{c}$ & $0.36 c$ \\
\hline
\end{tabular}

Table19. Size sorting of beans from four cultivars.

\begin{tabular}{|c|c|c|c|c|c|c|c|c|c|c|c|c|c|}
\hline & \multicolumn{12}{|c|}{ Pod size, mm } & \multirow[b]{2}{*}{ Day } \\
\hline \begin{tabular}{|l|} 
Days \\
\end{tabular} & $<7.0$ & $7.5-8.9$ & $9.5-11.0$ & $>11$ & $<7.0$ & & Day & $<7.0$ & $7.5-8.9$ & & & & \\
\hline Of & $80.8 \mathrm{a}$ & $17.7 \mathrm{e}$ & $1.4 \mathrm{f}$ & 0 & 3.5 & Corene & $28^{\text {th }}$ & Ofr & $50.0 \mathrm{a}$ & $47.3 \mathrm{a}$ & $2.8 \mathrm{f}$ & 0 & $25^{\text {th }}$ \\
\hline $36 \mathrm{e}$ & $49.7 b$ & $30.2 \mathrm{c}$ & $20.2 d$ & 0 & 6.3 & ; & $30^{\text {th }}$ & $16 \mathrm{e}$ & $26 . \mathrm{b}$ & $37.1 \mathrm{~b}$ & $37.4 \mathrm{e}$ & 0 & $29^{\text {th }}$ \\
\hline $50 \mathrm{~d}$ & $45.4 \mathrm{c}$ & $35.2 b$ & $18.8 \mathrm{e}$ & $0.62 \mathrm{~d}$ & 7.5 & " & $1 \mathrm{st}$ & $31 d$ & $19.6 \mathrm{c}$ & $36.6 b$ & $43.8 \mathrm{~d}$ & 0 & $31^{\mathrm{st}}$ \\
\hline $84 c$ & $26.1 d$ & $35.7 \mathrm{~b}$ & $32.9 \mathrm{c}$ & $3.38 \mathrm{c}$ & 10.6 & ; & $4^{\text {th }}$ & $58 \mathrm{c}$ & $12.8 \mathrm{~d}$ & $24.7 \mathrm{e}$ & $62.2 b$ & $0.3 \mathrm{c}$ & $4^{\text {th }}$ \\
\hline $100 \mathrm{~b}$ & $19.7 \mathrm{e}$ & $37.3 \mathrm{a}$ & $38.8 b$ & $4.23 \mathrm{~b}$ & 11.7 & $"$ & $6^{\text {th }}$ & $74 \mathrm{~b}$ & $8.5 \mathrm{f}$ & $22.8 \mathrm{~d}$ & $67.0 \mathrm{a}$ & $1.7 \mathrm{~b}$ & $6^{\text {th }}$ \\
\hline $115 \mathrm{a}$ & $17.1 \mathrm{f}$ & $22.6 \mathrm{~d}$ & $56.2 \mathrm{a}$ & $4.18 \mathrm{a}$ & 12.9 & " & $7^{\text {th }}$ & $81 a$ & $9.08 \mathrm{e}$ & $35.6 \mathrm{c}$ & $52.4 \mathrm{c}$ & $2.9 \mathrm{a}$ & $8^{\text {th }}$ \\
\hline Of & $47.6 \mathrm{a}$ & $36.7 \mathrm{~b}$ & $14.4 d$ & $1.3 \mathrm{~d}$ & 2.9 & " & Month & Days & $<7.0$ & $7.5-8.9$ & $9-11$ & $>11$ & $29^{17}$ \\
\hline $15 d$ & $36.2 b$ & $42.4 \mathrm{a}$ & $19.6 \mathrm{c}$ & $1.9 \mathrm{c}$ & 3.9 & Orbit & $25^{\text {th }}$ & Of & $80.8 \mathrm{a}$ & $17.7 \mathrm{e}$ & $1.4 \mathrm{f}$ & 0 & $31^{\mathrm{st}}$ \\
\hline $48 \mathrm{c}$ & $20.5 c$ & $27.6 \mathrm{~d}$ & $46.9 \mathrm{~b}$ & $5.03 \mathrm{~b}$ & 5.5 & . & $29^{\text {th }}$ & $36 \mathrm{e}$ & $49.7 \mathrm{~b}$ & $30.2 \mathrm{c}$ & $20.2 d$ & 0 & $4^{\text {th }}$ \\
\hline $65 b$ & $14.8 \mathrm{~d}$ & $29.9 c$ & $46 . \mathrm{pb}$ & $8.46 a$ & 6.4 & . & $31^{\mathrm{st}}$ & $50 \mathrm{~d}$ & $45.4 \mathrm{c}$ & $35.2 b$ & $18.8 \mathrm{e}$ & $0.62 d$ & $6^{\text {th }}$ \\
\hline $80 \mathrm{a}$ & $10.8 \mathrm{e}$ & $23.4 \mathrm{e}$ & $55.8 \mathrm{a}$ & $81 a$ & 7.3 & " & $4^{\text {th }}$ & $84 c$ & $26.1 \mathrm{~d}$ & $35.7 \mathrm{~b}$ & $32.9 \mathrm{c}$ & $3.38 \mathrm{c}$ & $8^{\text {th }}$ \\
\hline $0 \mathrm{e}$ & $93.19 \mathrm{a}$ & $6.8 \mathrm{e}$ & 0 & 0 & 4.5 & .6 & $6^{\text {th }}$ & $100 \mathrm{~b}$ & $19.7 \mathrm{e}$ & $37.3 \mathrm{a}$ & $38.8 \mathrm{~b}$ & $4.23 \mathrm{~b}$ & $24^{\text {th }}$ \\
\hline $37 d$ & $87.03 \mathrm{~b}$ & $13.3 \mathrm{~d}$ & 0 & 0 & 6.5 & 6 & $8^{\text {th }}$ & $115 a$ & $17.1 \mathrm{f}$ & $22.6 \mathrm{~d}$ & $56.2 \mathrm{a}$ & $4.18 \mathrm{a}$ & $28^{\text {th }}$ \\
\hline $53 c$ & $45.22 \mathrm{c}$ & $54.8 \mathrm{c}$ & 0 & 0 & 8.1 & Orbit & $29^{17}$ & of & $47.6 \mathrm{a}$ & $36.7 \mathrm{~b}$ & $14.4 \mathrm{~d}$ & $1.3 \mathrm{~d}$ & $30^{\text {th }}$ \\
\hline $68 b$ & $34.6 \mathrm{~d}$ & $65.0 \mathrm{~b}$ & $0.4 b$ & 0 & 9.1 & 6 & $31^{\mathrm{st}}$ & $15 d$ & $36.2 b$ & $42.4 \mathrm{a}$ & $19.6 \mathrm{c}$ & $1.9 \mathrm{c}$ & $1^{\mathrm{st}}$ \\
\hline $95 a$ & $20.8 \mathrm{e}$ & $78.3 a$ & $1.0 \mathrm{a}$ & 0 & 10.7 & 6 & $4^{\text {th }}$ & $48 c$ & $20.5 c$ & $27.6 \mathrm{~d}$ & $46.9 \mathrm{~b}$ & $5.0 \mathrm{~b}$ & $4^{\text {th }}$ \\
\hline Days & $<7.0$ & $7.5-8.9$ & $8.9-11.0$ & $>11$ & $\mathrm{t} \mathrm{ha}^{-1}$ & 6 & $6^{\text {th }}$ & $65 b$ & $14.8 \mathrm{~d}$ & $29.9 \mathrm{c}$ & 46.pb & $8.5 \mathrm{a}$ & Month \\
\hline Ofr & $50.0 \mathrm{a}$ & $47.3 \mathrm{a}$ & $2.8 \mathrm{f}$ & 0 & $2.9 \mathrm{f}$ & 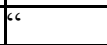 & $8^{\text {th }}$ & $80 a$ & $10.8 \mathrm{e}$ & $23.4 \mathrm{e}$ & $55.8 \mathrm{a}$ & $8.1 \mathrm{a}$ & $28^{\text {th }}$ \\
\hline
\end{tabular}

\section{REFERENCES}

[1] Kaack, K., V., Lindhard Pedersen, H. 2010, Prediction of diameter, weight and quality of apple fruit (Malus domestica Borkh.) cv. Elstar using Climatic Variables and their interactions. Europ. J. Hort. Sci. 75, 60-70.

[2] Kaack, K. 2016. Maturation and picking time for sweet cherries (Prunus avium) and sour Cherries (Prunus cerasus L.). Eur. Food Res. Technol. 235, 1438-2377.

[3] Dunlop, C. C., Ormrod. D. P. 1970. Temperature effects during fruit development on the quality of snap beans. Can. Inst. Food and Technol. 3. 6-8.

[4] Culpepper, C.W. 1936. Effects of stage and maturity of the snap bean on its composition as a food product. Food Res. 1. 357-376.

[5] Carr, D.F., Skeene, K.G.M. 1961. Diauxi growth curves of seeds with special reference to french bean (Phaseolus vulgaris L.). Aust. J. Biol. Sci. 14, 1-12.

[6] Cain, R. F., Sidwell A.P., Frazier W.A. 1953. Field behavior and processing characteristics of Blue Lake Beans. Oregon Oegon Agr. Exp. Sta. Wisc. Paper no 6.

[7] Guyer, R. B., Kramer. A. 1950. Factors affecting yield and quality measurements of raw and canned green and wax beans. Proc. Amer. Soc. Hort Sci. 56. 303-314.

[8] Moon, H.H., Caldwell, H.H., Lutz. J.M., Culpepper, C.V. 1936. 14 varieties of garden snap beans grown under eastern conditions. Canning Age 17. 271-275 and 284-290. 
[9] Caldwell, J.S. Hutchins. M.C., Ezell, B.D., Wilcox. M.S. 1944. Further studies of varietal suitability for dehydration in canned snap beans. Canner. 99, 9-18.

[10] Townsend, C.T., Somers, I. I., Lamb, F.C., Olson, N.A. 1965. Laboratory manual for the canning industry. National Canners Industry. New York.

[11] Sweeney, J.P. Martinez, M. 1958. Determination of chlorophyll and pheophytin in broccoly heated by various procedures. Food Res. 23, 637-647.

[12] Sharma, S. 1996. Applied Multivariate Techniques. John Wiley and Sons. New York 1996.

[13] Stevens, M., Lindsay, R.C., Libbey, L. M., Frazier, W.A. 1967. Volatile components of canned bean (Phaseolus vulgaris L.). Proc. Amer. Soc., Hort., Sci. 91, 833-845.

[14] Ferreira, M.E., de Varennes, A., de Melo-Abreu, J.P, Vieira, M.I. 2006. Predicting pod quality of green beans for processing. Sci. Hort. 109, 207-211.

[15] Yoldas, F., D. Esiyok, 2009. The influence of temperature on growth and yield of green beans for processing. Int. J. Agric. Res. 4: 124-130.

[16] Wolff, J.B., Price, L. 1960. The effects of sugars on chlorophyll biosynthesis in higher Plants 235, The J. Biol. Chem, 1603-1608.

[17] de Varennes A., de Melo-Abreu J.P., Vieira M. I.. 2006. Sci. Hort. 109, 207-211. 2006. Predicting pod quality of green beans for processing Sci. Hort. 109, 207-211.

[18] Kendall M. Stuart. A. 1977. The Advanced Theory of Statistics Vol. 1. Griffin. C. \& Company Limited. London.

[19] Ros, G., Rincón F., 1995. Physico-chemical and sensory quality criteria of green Beans (Phaseolus vulgaris, L LWT-Food Sci. Technol 28, 515-520.

[20] Lopez, J. 1995. Physico-chemical and sensory quality criteria of green beans (Phaseolus vulgaris, L.). Lebensm.-Wiss. u. Technol. 28,515-520.

[21] VandenLangenberg , K.M., Bethke, P.C. Nienhuis, J. 2012, Patterns of fructose, glucose, and sucrose accumulation in snap and dry bean and dry bean (Phaseolus vulgaris) HortScience 47, 874-878.

[22] De Cortes Sánchez-Mata, M., Cámara-Hurtado, M., Díez-Marqués C. 2002. Identification and quantification of soluble sugars in green beans by HPLC. Eur. Food Res. Technol. 214, 254-258.

[23] Reath, A.N. and S.H. Wittwer, 1952. The effect of temperature and photoperiod on the development of pea varieties. Am. Soc. Hortic. Sci., 60: 301-310.

[24] Rodrigo, M., A. Navarro, L. Duran, L. Vayaj and J. Safon, 1977. Seleccion de indices de madurez de jud1 as verdes para conserva. Revista Agroquımica Tecnologia Alimentos, 17: 95-110.

[25] Martínez, G. Ros, M.J. Periago, G. López, J. Ortũno and F. Rincón C. Physico-chemical and sensory quality criteria of green beans (Phaseolus vulgaris, L.) 1995. Lebensm.-W iss. Technol. 28, 515-520.

[26] Hoffman, J.C. (1971) Injury of snap bean pods associated with machine harvesting and handling. J. Am. Soc. Hort. Sci. 96.

[27] VandenLangenberg, K. M., Bethke, P.C., Nienhuis, J. 2012. Patterns of fructose, glucose, and sucrose accumulation in snap and dry bean (Phaseolus vulgaris) pods. HortScience 47, 874-878.

[28] De Cortes Sánchez-Mata, M.; Cámara-Hurtado M., Díez-Marqués - C. 2002. Identification and quantification of soluble sugars in green beans by HPLC. European Food Research and Technology 214, 254-258.

[29] Kaack, KV 1994. Blanching of green bean (Phaseolus vulgaris). Plant Foods for Human Nutrition, 46, 353-360.

Citation: K. Kaack, "Aarhus University, Kirstinebjergvej 10 Aarslev, Denmark", International Journal of Forestry and Horticulture, vol. 4, no. 2, p. 25-37, 2018. http://dx.doi.org/10.20431/2454-9487.0402004

Copyright: (C) 2018 K. Kaack. This is an open-access article distributed under the terms of the Creative Commons Attribution License, which permits unrestricted use, distribution, and reproduction in any medium, provided the original author and source are credited. 